\title{
Microorganisms as a Potential Source of Molecules to Control Trypanosomatid Diseases
}

\author{
Manuel Jesús Chan-Bacab *(D), María Manuela Reyes-Estebanez, Juan Carlos Camacho-Chab \\ and Benjamín Otto Ortega-Morales
}

\author{
Departamento de Microbiología Ambiental y Biotecnología, Universidad Autónoma de Campeche, \\ Av. Agustín Melgar s/n, Campeche 24039, Mexico; mamreyes@uacam.mx (M.M.R.-E.); \\ juanccam@uacam.mx (J.C.C.-C.); beortega@uacam.mx (B.O.O.-M.) \\ * Correspondence: manjchan@uacam.mx
}

Citation: Chan-Bacab, M.J.;

Reyes-Estebanez, M.M.;

Camacho-Chab, J.C.;

Ortega-Morales, B.O. Microorganisms as a Potential Source of Molecules to Control Trypanosomatid Diseases. Molecules 2021, 26, 1388. https:// doi.org/10.3390/molecules26051388

Academic Editor: Gilles Comte

Received: 21 January 2021

Accepted: 1 March 2021

Published: 4 March 2021

Publisher's Note: MDPI stays neutral with regard to jurisdictional claims in published maps and institutional affiliations.

Copyright: (c) 2021 by the authors. Licensee MDPI, Basel, Switzerland. This article is an open access article distributed under the terms and conditions of the Creative Commons Attribution (CC BY) license (https:// creativecommons.org/licenses/by/ $4.0 /)$.
Abstract: Trypanosomatids are the causative agents of leishmaniasis and trypanosomiasis, which affect about 20 million people in the world's poorest countries, leading to 95,000 deaths per year. They are often associated with malnutrition, weak immune systems, low quality housing, and population migration. They are generally recognized as neglected tropical diseases. New drugs against these parasitic protozoa are urgently needed to counteract drug resistance, toxicity, and the high cost of commercially available drugs. Microbial bioprospecting for new molecules may play a crucial role in developing a new generation of antiparasitic drugs. This article reviews the current state of the available literature on chemically defined metabolites of microbial origin that have demonstrated antitrypanosomatid activity. In this review, bacterial and fungal metabolites are presented; they originate from a range of microorganisms, including cyanobacteria, heterotrophic bacteria, and filamentous fungi. We hope to provide a useful overview for future research to identify hits that may become the lead compounds needed to accelerate the discovery of new drugs against trypanosomatids.

Keywords: microbial metabolites; antitrypanosomatid agents; leishmaniasis; trypanosomiasis

\section{Introduction}

Infectious tropical diseases constitute a problem for many human beings that inhabit tropical areas of our planet. Affecting people who live in developing countries, these neglected diseases are caused by viruses, protozoa, helminths, and bacteria, which generate different symptoms and may often lead to death [1]. Parasitic diseases have an overwhelming impact on public health, and their geographical distribution favors climates that allow vector persistence for transmission. Vector control is possible, eradication is probably not possible, and vaccine development has so far been unsuccessful, as parasites are experts at evading or deregulating the human immune system [2,3].

Trypanosomatids are flagellated unicellular protozoan parasites belonging to the order Kinetoplastida, family Trypanosomatidae. They are characterized by a single, large mitochondrion that extends through most of these organisms' bodies, and whose DNA creates a unique and elaborate structure called the kinetoplast, located near the flagellar basal body $[4,5]$. Several species within the Trypanosomatidae family are responsible for the severe but largely neglected diseases of humans and domestic animals, such as Leishmania and Trypanosoma, the causative agents of leishmaniasis, American trypanosomiasis (Chagas disease), and Human African trypanosomiasis [6,7].

Although leishmaniasis and trypanosomiasis are targeted for control or eradication by the World Health Organization Division of Control of Tropical Diseases, most available drugs are associated with prolonged treatments, high toxicity, and the emergence of drug resistance or a lack of treatment adherence and, therefore, there is a need for new drugs [8]. In recent years, non-profit research and development organizations, academic and insti- 
tutional centers, and public-private partnerships with pharmaceutical companies have succeeded in discovering new drugs, which must be evaluated in various clinical phases [9].

The ongoing search for new drugs to treat different diseases has been focused on nature because natural sources have continuously provided humanity with broad and structurally diverse pharmacologically active compounds. These continue to be utilized as highly effective drugs to combat many deadly diseases, or as lead structures to develop novel-synthetically derived compounds. Traditionally, higher plants and, since the discovery of penicillins, terrestrial microorganisms have proven to be the richest sources of natural drugs that are indispensable for treating several diseases [10]. Natural products are a source of antiprotozoal drugs. For example, for malaria treatment, quinine was isolated from Cinchona species, and, later, artemisinin was obtained from Artemisia annua [11]. Although infrequently mentioned, the leishmanicidal agents, amphotericin B and paromomycin, are produced by the actinobacteria Streptomyces nodosus and S. krestomuceticus, respectively $[12,13]$. For this reason, the present review focuses on gathering information about metabolites produced by bacteria and fungi, which could be consideredas hits in the development and design of new drugs for the treatment of trypanosomatid diseases in the future.

\section{Trypanosomatid Diseases}

Leishmaniasis comprises a group of diseases with different clinical manifestations caused by various species of Leishmania parasites. Twenty species are known to cause infections and drive the four clinical forms of the disease: cutaneous, diffuse cutaneous, mucocutaneous and visceral leishmaniasis. Cutaneous forms are produced by L. mexicana or L. braziliensis complexes in the Americas and L. major, L. tropica, or L. aethiopica in the Old World. Cutaneous lesions resolve spontaneously after some months but, depending on the Leishmania species causing them, they can evolve into diffuse cutaneous and mucocutaneous leishmaniasis [14]. Visceral leishmaniasis is caused by L. infantum in Latin America [15], L. donovani in Africa and Asia, or L. infantum in the Mediterranean basin, which can be fatal if not treated [14].

Current chemotherapy for leishmaniasis has many drawbacks, including low efficacy, severe toxic side effects, and the appearance of drug resistance. The first effective drug, ureastibamine, was developed in India in 1922, but it had severe side effects. Later, the refinement and development of pentavalent antimonials reduced the side effects. These compounds remain crucial in the treatment of all forms of leishmaniasis. However, reports of non-response to pentavalent antimony began in the 1970s, even at higher doses, and several other side effects of this regimen were reported, including pancreatic inflammation, nausea, and abdominal pain, pancytopenia, peripheral neuropathy, and cardiotoxicity. This led to trials with pentamidine and amphotericin B. Pentamidine's reported side effects were myalgia, pain at the injection site, nausea, headache, and, less commonly, an oral metallic taste, a burning sensation, numbness, and hypotension $[16,17]$. Amphotericin B is highly nephrotoxic and, to minimize these side effects, several formulations of colloids and lipids were prepared. These preparations are comparatively safe but extremely expensive. Later, miltefosine was introduced to the market, but the drug is teratogenic and, thus, the administration is contraindicated during pregnancy and shows severe gastrointestinal side effects. Moreover, its cost is another limiting factor. Finally, other drugs, such as paromomycin, allopurinol, and sitamaquine, have been reported with variable cure rates [17].

American trypanosomiasis (Chagas disease), caused by the protozoan parasite Trypanosoma cruzi, is characterized by a generalized infection that clinically courses from an acute form to a chronic phase. The chronic phase of the disease is highly disabling due to cardiac and digestive disorders that can eventually lead to death. This flagellated protozoan parasite is transmitted to humans by a blood-sucking reduviid bug, which deposits its infective feces on the skin at the time of biting. It can also be transmitted directly by infected blood or by congenital transmission $[6,18]$. The drugs currently used for Chagas disease's etiological treatment are nitroimidazole, benznidazole, and nitrofuran, 
nifurtimox. The benefits of benznidazole are most significant during the acute stages of the disease in adults and children, and young adults with intermediate Chagas disease [19]. Benznidazole prevents congenital transmission when administered to reproductive-age women, which may be an essential strategy to prevent disease in newborns [20]. Tolerance to benznidazole is satisfactory since no severe side effects have been observed in treated patients. Side effects include allergy, skin disease, nausea, and vomiting. Less common are polyneuropathy and bone marrow depression. Nifurtimox is used as a second-line option for the treatment of this disease. Several clinical studies have shown that this drug, in children and adults, achieved a cure rate of $80-90 \%$. However, its adverse side effects are common and include anorexia, vomiting, gastric pain, insomnia, headache, myalgia, and seizures [21,22].

Following the bite of the tsetse fly of the genus Glossina, Human African trypanosomiasis (HAT) can occur in two clinical forms: a chronic form caused by Trypanosoma brucei gambiense, found mainly in West and Central Africa, representing more than $98 \%$ of recorded cases, and an acute form, caused by Trypanosoma brucei rhodesiense, found mainly in Eastern and South-Central Africa. Without treatment, both types of parasites penetrate the blood-brain barrier and invade the CNS, manifesting in complex symptoms that lead to patient death [23]. Drug treatment in the early stage of HAT is effective and less toxic than in the late stage. Pharmacotherapy for T. $b$. gambiense consists of intramuscular or intravenous pentamidine. For late-stage disease, the first-line therapy for T. b. gambiense is NECT, a combination of intravenous eflornithine (DFMO), an ornithine decarboxylase inhibitor, and oral nifurtimox [24]. Finally, fexinidazole, a derivative of 5-nitroimidazole, is a DNA synthesis inhibitor developed by Sanofi in collaboration with the Drugs for Neglected Diseases initiative (DNDi) for the treatment of HAT [25]. Fexinidazole is the first oral drug treatment for the disease's early and late stages [26,27].

\section{Population Affected by these Diseases}

The World Health Organization (WHO) has reported that leishmaniasis affects 98 countries, with between 12 and 15 million people infected. Additionally, around 50,000 to 90,000 new cases of visceral leishmaniasis and 600,000 to 1 million cases of cutaneous leishmaniasis are reported annually worldwide, leading to between 26,000 and 65,000 deaths $[28,29]$. There is evidence that Leishmania-HIV co-infections are becoming a significant health problem in affected areas [30].

Chagas disease is an endemic disease widespread in 21 countries from the southern United States to southern Argentina. It has been estimated that around 6-7 million people are infected with $T$. cruzi, the agent responsible for this disease, with an annual average incidence of 30,000 new cases and 14,000 deaths. About 70 million people live in exposure areas and are at risk of contracting this disease [31]. Finally, HAT is a daily threat to more than 60 million people in 36 Sub-Saharan African countries, including 22 of the world's least-developed countries. Sustained control efforts have reduced the number of new cases. In 2009, the number of reported cases fell below 10,000 for the first time, and only 977 cases were recorded in 2018 [32].

\section{Microbial Diversity as a Source of Antiprotozoal Metabolites}

Natural resources are recognized as important sources of potential drugs for treating various infections, and microorganisms are a rich natural source of diverse compounds [33]. The discovery of penicillin from Penicillium notatum marked a significant shift from plants to microorganisms as a source of natural products. The early years of antibiotic research discovered streptomycin from Streptomyces griseus, cephalosporin C from Cephalosporium acremonium, erythromycin from Saccharopolyspora erythraea, and vancomycin from Amycolatopsis orientalis [34]. Moreover, it is worth noting that two drugs used to treat leishmaniasis, amphotericin B and paromomycin, were isolated from S. nodosus and S. krestomuceticus, respectively $[12,13]$. 
To the best of our knowledge, few reviews are deal with bacterial and fungal metabolites against trypanosomatid parasites [11,35-37] since these reviews only briefly mention them.

\section{Bacterial Metabolites}

In nature, most bacteria exist attached to surfaces within biofilms and are inherently different from those in the planktonic state, due to a change in their metabolism. Thus, these microorganisms produce anti-predator secondary metabolites, which may be considered as potential new bioactive products [38].

\subsection{Actinobacteria}

Among these microorganisms, actinomycetes abundant in soil and marine organisms are well-known producers of a wide range of bioactive secondary metabolites and antibiotics [33]. Manzamines are complex polycyclic marine-derived alkaloids that possess a fused and bridged tetra- or pentacyclic ring system attached to a $\beta$-carboline moiety [39]. Manzamines have been found in several species belonging to the Chalinidae, Niphatidae, Petrosidae, Theorectidae, and Irciniidae families of marine sponges worldwide [39,40]. To date, approximately 40 related compounds have been reported, with manzamine A (1) (Figure 1) being the most important. This metabolite exhibited a 50\% inhibitory concentration $\left(\mathrm{IC}_{50}\right)$ of $1.63 \mu \mathrm{M}$ against the promastigotes of $L$. donovani as well as an $\mathrm{IC}_{50}$ of $2.18 \mu \mathrm{M}$ against mammalian kidney fibroblasts (Vero cells), demonstrating only slight selective activity against the parasites [41]. Studies on the structure-activity relationship established that, for leishmanicidal activity, the C-12 hydroxy, C-34 methine, or lower aliphatic ring conformation are indispensable, whereas the $\beta$-carboline moiety is not essential $[41,42]$. Finally, because of the presence of manzamines in multiple sponge species with wide geographical distribution, it has been suggested that manzamine could be of microbial origin. This was demonstrated when an actinomycete Micromonospora sp., which produces manzamine A and 8-hydroxy-manzamine, was isolated from the sponge Acanthostrongylophora ingens [40,43]. Additionally, from Micromonospora sp., lobosamide A (2), which is a 26-membered macrolactam, was isolated and exhibited activity against T. b. brucei at $0.8 \mu \mathrm{M}$ and low cytotoxicity to T98G cells $(>66 \mu \mathrm{M})$. The structure-activity relationship with lobosamide $\mathrm{A}$ analogs established that the isomerization of the double bond between carbons C-14 and C-15 is unfavorable. In contrast, a hydroxyl group at C-10 and the methylation pattern at carbons C-8 and C-20 are significant for trypanocidal activity [44].

Valinomycin (3), a cyclodepsipeptide recovered from various soil-derived actinomycetes (Streptomyces fulvissimus, S. roseochromogenes, and S. griseus var. flexipertum) was isolated from a marine Streptomyces sp. found in the sponges Axinella polypoides and Aplysina aerophoba. This metabolite exhibited significant inhibitory activities against the parasites L.major $\left(\mathrm{IC}_{50}<0.11 \mu \mathrm{M}\right)$ and $T$. b. brucei $\left(\mathrm{IC}_{50}=0.0032 \mu \mathrm{M}\right)$. Additionally, it exhibited cytotoxicity against $293 \mathrm{~T}$ kidney epithelial cells $\left(\mathrm{IC}_{50}=11.2 \mu \mathrm{M}\right)$ and J774.1 macrophages $\left(\mathrm{IC}_{50}<0.1 \mu \mathrm{M}\right)$. Its biological activity could be due to the nonpolar portion of the molecule, which behaves similar to an ionophore that modulates the transport of ions such as potassium, across biological membranes [45].

The actinobacterium $S$. axinellae isolated from the sponge Axinella polypoides produced five compounds, called tetromycins. These compounds were active against the trypomastigotes of T. b. brucei but were also toxic to 293T kidney cells and J774.1 macrophages, excluding tetromycin 1 (4), which had an $\mathrm{IC}_{50}$ of $31.7 \mu \mathrm{M}$ and no cytotoxic activity to both cell lines at a concentration of $100 \mu \mathrm{M}$ [46].

Several actinobacteria strains isolated from ant exoskeletons have recently emerged as a prolific and underexplored source of microbial compounds. The bacterium, Streptomyces sp. ICBG292, isolated from Cyphomyrmex exoskeletons, produced a polyether antibiotic known as nigericin (5), which was first isolated from S. hygroscopicus in the 1950s [47]. This metabolite was active against $L$. donovani promastigotes and amastigotes, with $\mathrm{IC}_{50}$ values of $0.28 \mu \mathrm{M}$ and $0.13 \mu \mathrm{M}$, respectively. Additionally, Streptomyces sp. ICBG233, 
isolated from Atta sexdens exoskeletons, generated a macrotetrolide, called dinactin (6), which also exhibited activity against $L$. donovani promastigotes and amastigotes at $\mathrm{IC}_{50}$ values of $0.03 \mu \mathrm{M}$ and $0.02 \mu \mathrm{M}$, respectively. These metabolites were more active than the positive control (miltefosine) and, although they presented cytotoxic activity against THP-1 cells, they had high selectivity indexes, 89 for nigericin and 656 for dinactin [48]. Finally, these compounds are considered ionophores that bind reversibly and transport ions across biological membranes. Nigericin moves sodium and potassium ions across membranes [49]. Dinactin is a member of the nactin family, with the ability to selectively complex a wide variety of cations [48].

Oligomycin (7), a 26-membered macrolactone with a spiroketal ring isolated from Streptomyces diastatochromogenes, exhibited activity against T. brucei S42 at $3.8 \mu \mathrm{M}$, causing the inhibition of glucose utilization, since pyruvate production was not observed, as well as oxygen consumption [50,51]. Later, it was determined that oligomycin inhibits mitochondrial ATP synthase by promoting the induction of glucose uptake through the AMP-activated protein kinase (AMPK) and protein kinase B (Akt) pathways while preventing the intracellular uptake of calcium ions [52]. Finally, this metabolite exhibited activity against amastigotes forms of the T. cruzi, expressing galactosidase (Tulahen strain) in Vero cells at an $\mathrm{IC}_{50}$ of $0.52 \mu \mathrm{M}$. However, in vivo studies with Balb/c mice were not performed due to its toxicity [53].

Calcimycin (8) (antibiotic A23187), a carboxylic polyether isolated from Streptomyces chartreusensis [54] and a selective ionophore for divalent cations, particularly $\mathrm{Ca}^{2+}, \mathrm{Mg}^{2+}$, and $\mathrm{Mn}^{2+}$ [55], demonstrated activity against intracellular amastigotes of Leishmania enriettii at concentrations between $0.01-0.25 \mu \mathrm{M}$, by observing the decreased incorporation of ${ }^{3}[\mathrm{H}]$-thymidine into parasites released from sodium dodecyl sulfate (SDS)-lysed and lipopolysaccharide(LPS)-stimulated macrophages [56]. Subsequently, in another study, the pretreatment of peritoneal macrophages from Balb/c mice with calcimycin at a concentration of $1 \mu \mathrm{M}$ for $48 \mathrm{~h}$ before their infection with Leishmania major led to a decrease in the incorporation of ${ }^{3}[\mathrm{H}]$-thymidine by intracellular amastigotes [57]. Its action mechanism was recently confirmed in L. major promastigotes co-incubated with calcimycin by evaluating the activity with resazurin. Calcimycin showed a dose-dependent effect with an $\mathrm{IC}_{50}=0.16 \mu \mathrm{M}$. In this study, it was shown that, at lower concentrations, calcimycin had a cytostatic effect and, at higher concentrations, a cytotoxic effect, causing the cell death of Leishmania parasites due to the loss of mitochondrial polarization and plasma membrane integrity, which can be blocked by specific inhibitors of constitutive $\mathrm{Ca}^{2+} /$ calmodulin nitric oxide synthase [58].

The co-culture of two sponge-derived actinomycetes, Actinokineospora sp. EG49 and Nocardiopsis sp. RV163 produced 1,6-dihydroxyphenazine (9), which was active against T. brucei parasites with an $\mathrm{IC}_{50}$ value of $19 \mu \mathrm{M}$ [59]. Additionally, the O-glycosylated angucycline, actinosporin A (10), isolated from the culture of Actinokineospora sp. EG49 exhibited activity against $T$. b. brucei with an $\mathrm{IC}_{50}$ of $15 \mu \mathrm{M}$ [60].

From solid cultures elicited with the $N$-acetyl glucosamine of Actinokineospora spheciospongiae, isolated from the sponge Spheciospongia vagabunda, produced an anthraquinone called fridamycin H (11), which showed activity against Trypanosoma brucei strain TC 221 after 48 and $72 \mathrm{~h}$ with $\mathrm{IC}_{50}$ values of 7.18 and $3.35 \mu \mathrm{M}$, respectively. Moreover, it did not present cytotoxic activity against J774.1 macrophages with an $\mathrm{IC}_{50}$ of $>200 \mu \mathrm{M}$. Therefore, this strategy of inducing compounds by elicitation may allow for new bioactive chemical scaffolds [61].

\subsection{Cyanobacteria}

Marine cyanobacteria are a source of many novel natural product structures, some of which possess highly potent biological properties. Several metabolites are partially composed of amino acids, and these are often integrated with sections of polyketides to produce various nitrogen-rich lipids. Oxidations, methylations, and even halogenations often modify the chemical structures of these compounds. Symplocamide A (12), a bromide 
depsipeptide isolated from a marine cyanobacterium, Symploca sp., showed antiprotozoal activity against $L$. donovani and $T$. cruzi $\left(\mathrm{IC}_{50}>9.5 \mu \mathrm{M}\right)$. However, it is also a highly cytotoxic metabolite against NCI-H460 (non-small cell lung cancer) and neuro-2A (mouse neuroblastoma) cell lines [62].

The cyclic hexapeptides, venturamides A and B, isolated from the marine cyanobacterium Oscillatoria sp. showed weak selectivity for the L. donovani and T. cruzi parasites versus mammalian host cells. Venturamide A (13) showed in vitro activity against $T$. cruzi $\left(\mathrm{IC}_{50}=14.6 \mu \mathrm{M}\right)$, with only mild cytotoxicity to mammalian Vero cells $\left(\mathrm{IC}_{50}=86 \mu \mathrm{M}\right)$. Venturamide B (14) displayed antiprotozoal activity against T. cruzi at an $\mathrm{IC}_{50}$ of $15.8 \mu \mathrm{M}$, and mild cytotoxicity to Vero cells $\left(\mathrm{IC}_{50}=56 \mu \mathrm{M}\right)$ [63].

Another species of Oscillatoria, O. nigro-viridis, isolated as an epiphytic species from a partially purified culture of cyanobacterium Lyngbya majuscula, was active against axenic amastigotes of L. mexicana and amastigotes of T. cruzi in Vero cells. Its lipodepsipeptide, viridamine $\mathrm{A}(\mathbf{1 5})$, had antileishmanial activity at an $\mathrm{IC}_{50}$ of $1.5 \mu \mathrm{M}$ and antitrypanosomal activity at an $\mathrm{IC}_{50}$ of $1.1 \mu \mathrm{M}$ [64].

Coibacin A (16), a polyketide $\alpha, \beta$-unsaturated- $\delta$-lactone with a methyl cyclopropyl ring in its linear chain, isolated from the marine cyanobacterium Oscillatoria sp., exhibited selective activity to axenic amastigotes of $L$. donovani at a concentration of $2.4 \mu \mathrm{M}$ and showed cytotoxic activity against NCI-H460 human lung cancer cells at $31.5 \mu \mathrm{M}$. However, coibacin A did not show activity against intracellular amastigotes of Leishmania mexicana in RAW264.7 mouse macrophage cells, possibly due to not being able to cross the plasma membrane of these cells [65].

A linear peptide, dragonamide $\mathrm{E}$ (17), and two known linear peptides, dragonamide $\mathrm{A}$ (18) and herbamide B (19), were isolated from an extract of marine cyanobacteriumLyngbya majuscula. These compounds were active against the L. donovani axenic amastigote with an $\mathrm{IC}_{50}$ between 5.1 and $6.5 \mu \mathrm{M}$, and this activity is due to the presence of a residue containing an aromatic ring at the end of the peptide [66]. Other metabolites of L. majuscula closely related to dragonamide A, almiramides B (20) and C (21), which contain an extra Ala residue, no methyl group on Val 1, and the opposite configuration of the $\alpha$-carbon of the lipophilic side chain, showed better antileishmanial activity against $L$. donovani with $\mathrm{IC}_{50}$ values of 2.4 and $2 \mu \mathrm{M}$, respectively. However, these compounds were also cytotoxic to Vero cells $[67,68]$. Despite significant structural similarities between these compounds, an unsaturated terminus on the lipophilic side chain seems to play a critical role in antileishmanial activity in dragonamides and almiramides [67]. Improved leishmanicidal activity is also due to the methylation patterns that determine the degree of membrane permeability [68].

Another linear peptide, gallinamide A (22), isolated from the organic extract of a marine cyanobacterium, Schizothrix sp., was moderately active against $L$. donovani $\left(\mathrm{IC}_{50}=9.3 \mu \mathrm{M}\right)$ and showed in vitro cytotoxicity toward Vero cells $\left(\mathrm{TC}_{50}=10.4 \mu \mathrm{M}\right)$. However, it was not toxic against NCI-H460 human lung tumor and neuro-2a mouse neuroblastoma cell lines at $17 \mu \mathrm{M}$. This metabolite contains the unusual 4-(S)-amino-2(E)-pentenoic acid subunit and the presence of a methyl-methoxypyrrolinonemoiety at the C-terminus, and its leishmanicidal activity is related to the presence of a terminal $\mathrm{N}, \mathrm{N}$-dimethyl-isoleucine group [69].

The $\beta$-carboline alkaloid, nostocarboline (23), derived from the cyanobacterium Nostoc 78-12A, was synthetized and evaluated against different parasites. Against axenic amastigotes of L. donovani, the alkaloid presented an IC50 value of $34.3 \mu \mathrm{M}$, whereas its cytotoxicity in the L6 myoblast cells of rats was $121 \mu \mathrm{M}$ [70].

A cyclic depsipeptide, named janadolide (24), was isolated from a marine cyanobacterium Okenia sp. This metabolite exhibited potent antitrypanosomal activity with an $\mathrm{IC}_{50}$ of $47 \mathrm{nM}$ against the T. brucei GUTat 3.1 strain and had no cytotoxic effect against MRC-5 cells $(>10 \mu \mathrm{M})$ [71]. In attempting to synthesize this compound, which is a 23-membered macrocyclic and a rare polyketide-peptide hybrid containing a tert-butyl group, it was observed that this functional group is essential for parasitic activity [72]. Recently, other researchers synthesized janadolide, which had in vitro antitrypanosomal activity against the 
pathogenic parasites T.b. rhodesiense (STIB900 strain) and T. cruzi (Tulahuen C4 strain) with $\mathrm{IC}_{50}$ values of 91.3 and $69.3 \mu \mathrm{M}$, respectively. Additionally, eight analogs were synthesized, which were not cytotoxic to human L6 cell lines at high concentrations between 100-150 $\mu \mathrm{M}$. The structure-activity relationship suggests that the replacement of the olefin moiety and ester bond with amide bonds does not compromise the compound's activity [73].

\subsection{Firmicutes}

The bacterium Bacillus pumilus isolated from the coral mucus Antiphates sp. produced three indole alkaloids with selective activity against T. cruzi amastigotes expressing $\beta$-galactosidase (Tul- $\beta$-Gal) in Vero cells. The compounds 3-hydroxyacetylindole (25), $N$-acetyl- $\beta$-oxotryptamine (26), and 3-formylindole (27) presented similar trypanocidal activities with $\mathrm{IC}_{50}$ values of 20.6, 19.4, and $27 \mu \mathrm{M}$, respectively. Likewise, the compounds $N$-acetyl- $\beta$-oxotryptamine and 3-formylindole showed no significant cytotoxic activity against Vero cells. Due to their similarity in their chemical structures, it is possible that the presence of a carbonyl group in C-1 of the lateral chain, being an electron-attracting group, is responsible for the antiprotozoal activity [74].

\subsection{Gammaproteobacteria}

Polyketides, such as the 3,6-dialkyl-4-hydroxy-2-pyrone marine metabolites, pseudopyronines A (28) and B (29), isolated from the fermentation broth of Pseudomonas sp., were synthesized, and evaluated against L. donovani axenic amastigotes, T. $b$. rhodesiense trypomastigotes, and T. cruzi amastigotes. Both metabolites had leishmanicidal activity with $\mathrm{IC}_{50}$ values of 9.8 and $4.65 \mu \mathrm{M}$, respectively, and weak cytotoxic activity against the L6 rat skeletal myoblast cell line; their selectivity indices were 8.8 (pseudopyronine A) and 13 (pseudopyronine B). However, these metabolites had no significant activity against Trypanosoma species. Additionally, a small set of structurally related compounds were evaluated against these parasites, which were more active against L. donovani. A probable action mechanism of these metabolites is the inhibition of enzymes involved in fatty acid biosynthesis in the protozoan parasites [75].

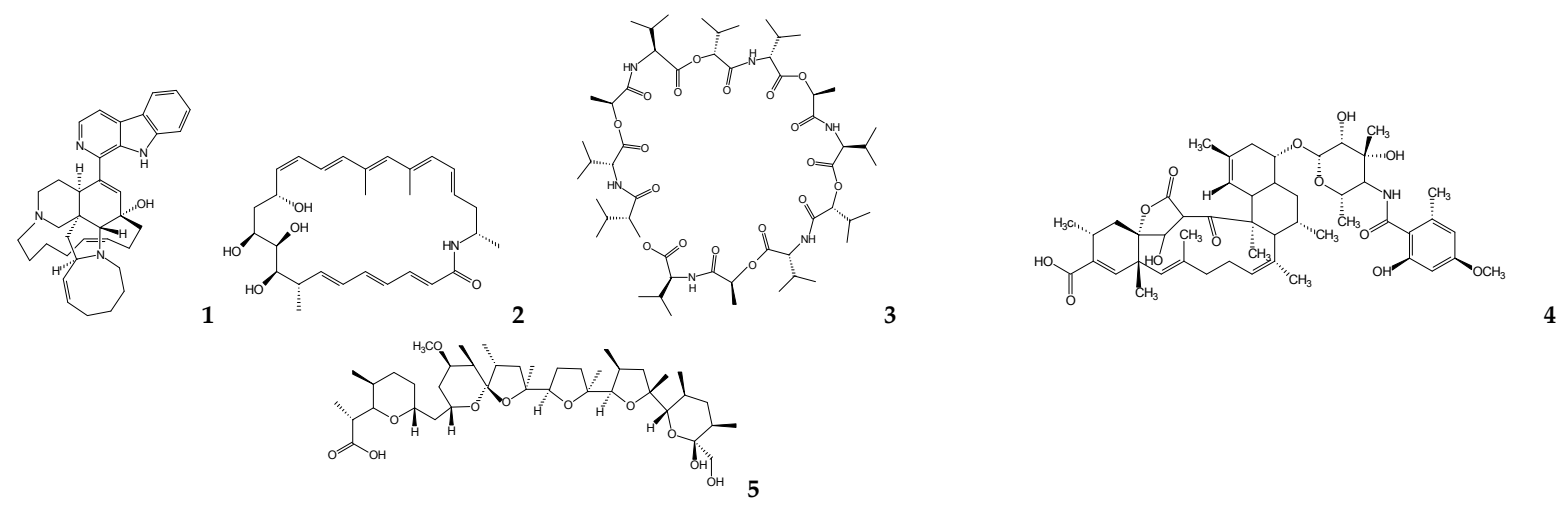

Figure 1. Cont. 

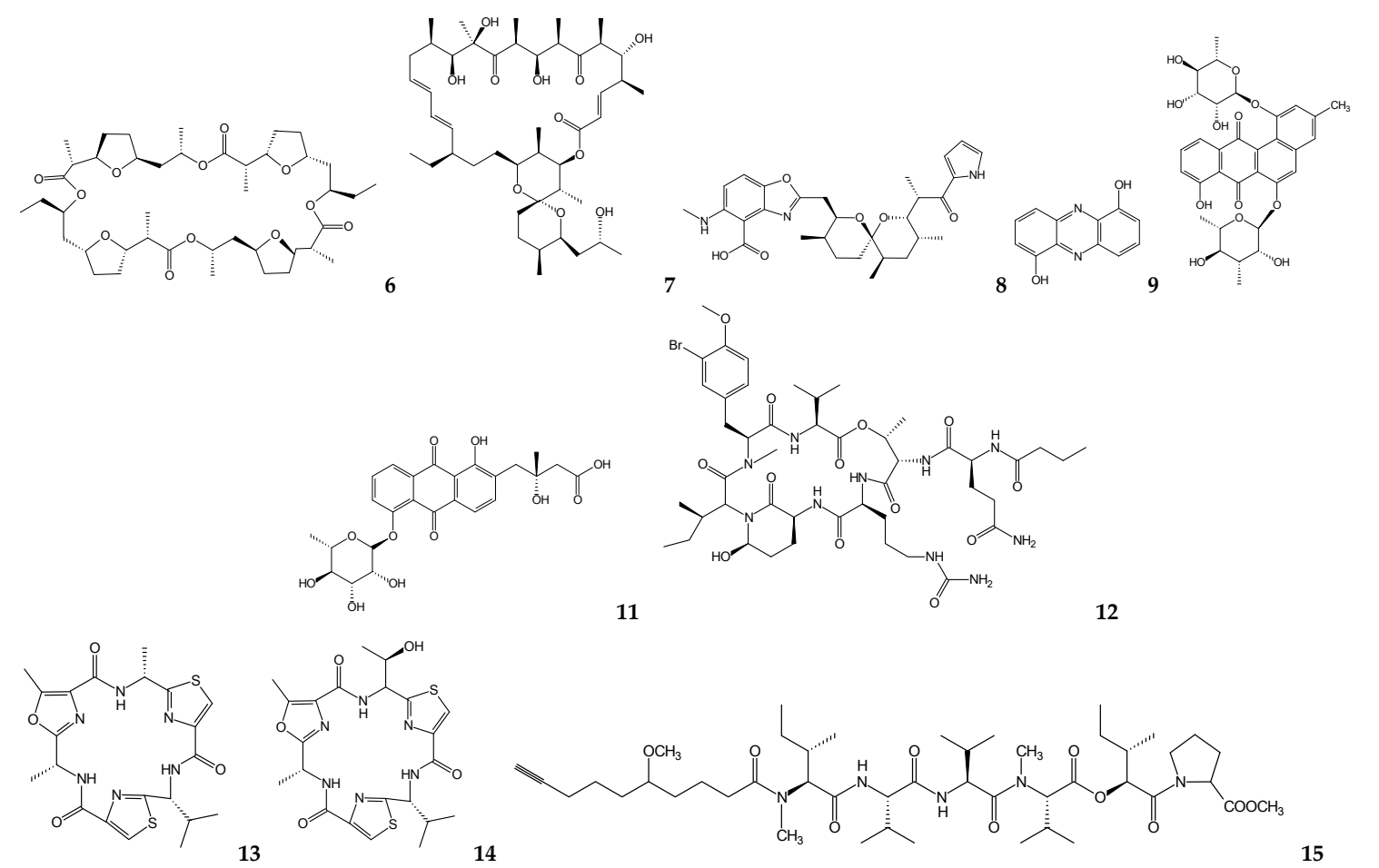

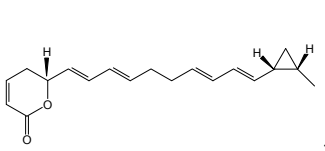

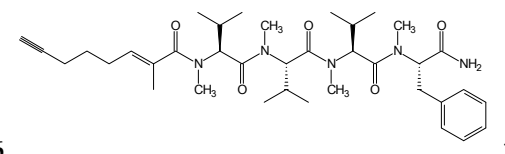<smiles>CCCCCC(C)C(=O)C(C)C(C(=O)C(C(C)C)C(O)C(C)C)C(C)C(C(C)C)C(C)C(=O)C(CC1CCCCC1)C(C)C(C)C</smiles>

16

17

18

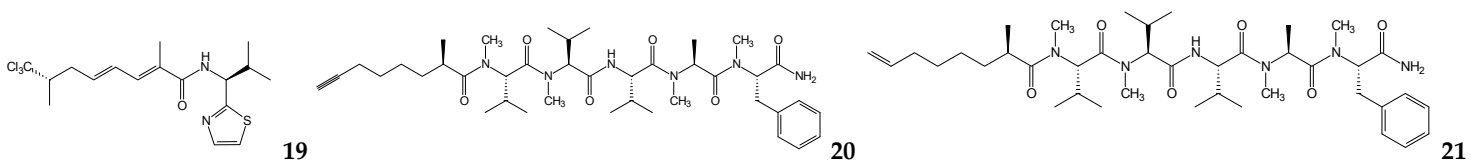

20

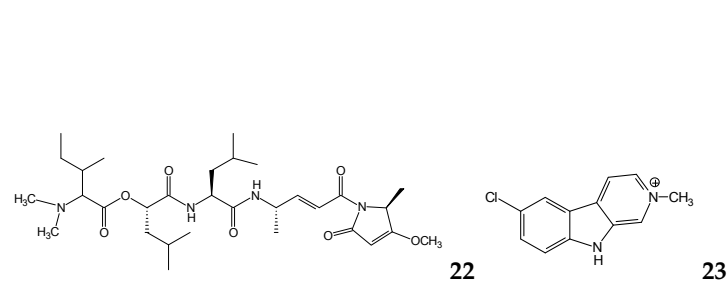

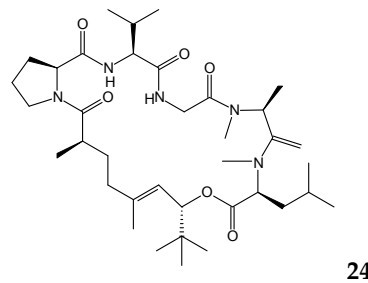<smiles>O=C(CO)C1CC=C2C=CC=CC21</smiles><smiles>CC(O)CCC(O)C1CC2CCNC2C1</smiles><smiles>O=CC1CNC2CCCCC12</smiles><smiles>CCCCCCC1C(=O)OC(CCCCC)CC1O</smiles><smiles>CCCCCCC1CC(O)C(CCCCCC)C(=O)O1</smiles>

Figure 1. Chemical structures of bacterial metabolites with antitrypanosomatid activity.

\section{Fungal Metabolites}

\section{Ascomycetes}

Fungal secondary metabolites possess broad bioactive applications, and different classes of fungal metabolites have antiprotozoal potential. Aphidicolin (30) (Figure 2), a tetracyclic diterpene antibiotic isolated from the fungus Nigrospora sphaerica, was tested against Trypanosoma spp. and Leishmania spp. At $0.3 \mu \mathrm{M}$, it inhibited cell division but did not inhibit the DNA synthesis of T. brucei bloodstream forms. Higher concentrations of aphidicolin $(3$ and $29 \mu \mathrm{M})$ were needed to inhibit DNA synthesis, and the cells failed to resume growth after removing the drug [76]. Concerning Leishmania parasites, aphidicolin has been evaluated against the promastigote forms of Leishmania donovani, L. infantum, L. enrietti, and L. major, which were active in all of them with mean effective doses $\left(\mathrm{EC}_{50}\right)$ that ranged between 0.41 and $1.6 \mu \mathrm{M}$. Additionally, it did not present toxic activity against 
two neoplastic cell lines (squamous carcinoma (KB) and melanoma (SK-Mel)) and murine bone marrow-derived macrophages as host cells (BMMØ). Remarkably, against $L$. donovani amastigotes in BMMØ cells, it had an $\mathrm{EC}_{50}$ of $0.35 \mu \mathrm{M}$, with a selectivity index towards parasites. Although aphidicolin possesses the selective inhibition of leishmanial and mammalian DNA polymerases, the specific differences in the target enzyme DNA polymerase between mammalian cells and trypanosomatid parasites give a plausible explanation for the different activities of these compounds against host cells and Leishmania parasites [77].
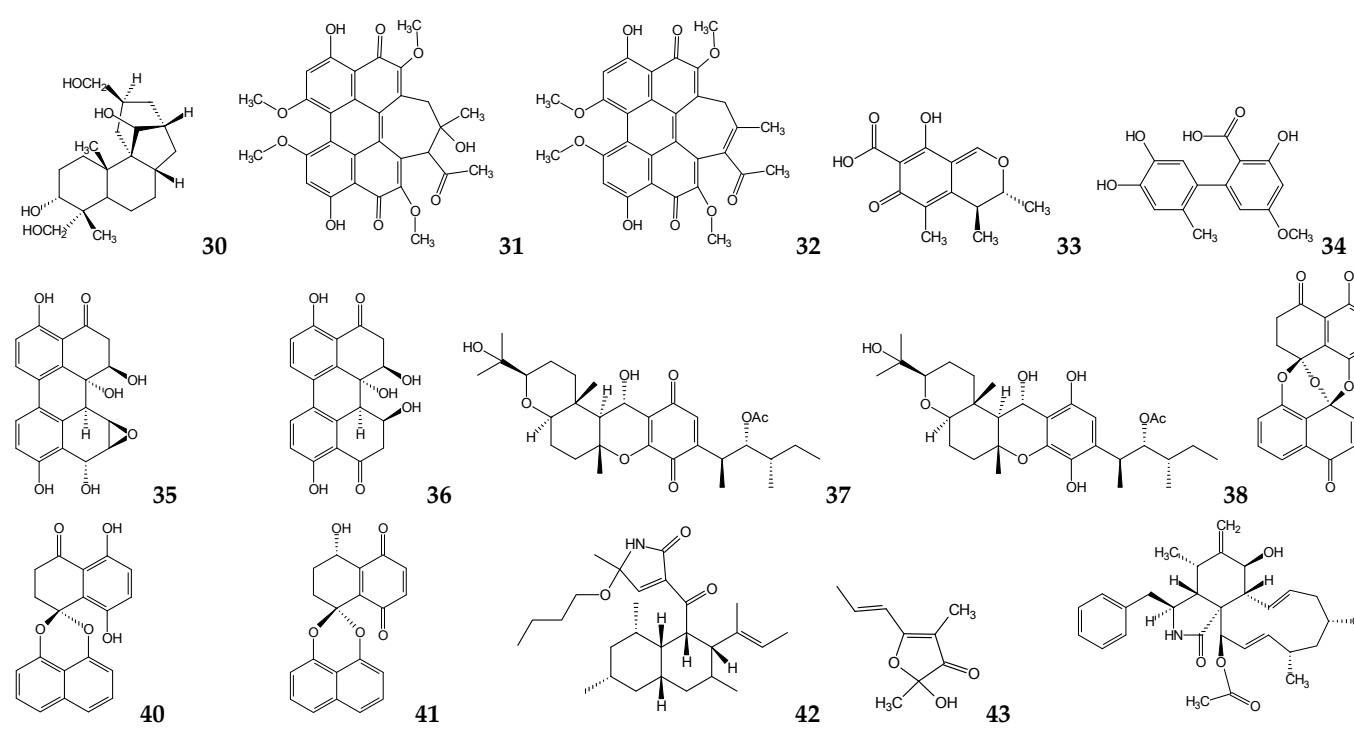

41

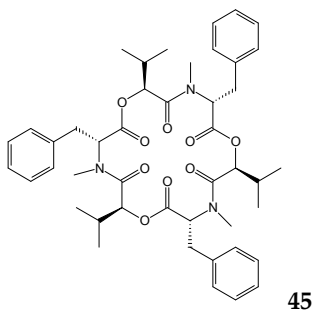

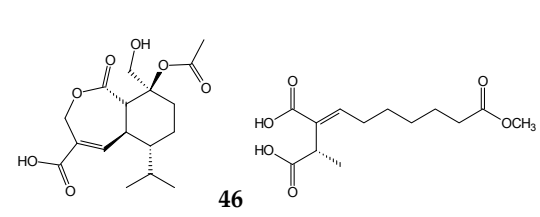

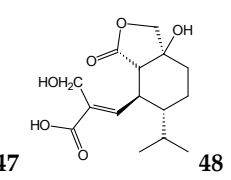

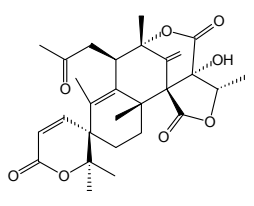<smiles>C/C(=C\Cc1c(O)c(Cl)c(C)c(C=O)c1O)CC/C=C(\C)[C@H]1CC(=O)C(C)(C)O1</smiles><smiles>CC(=CCc1c(C)c2c(c(O)c1O)C(=O)OC2)CCC(=O)O</smiles>

50<smiles>C=C1CC(O)CC(CCC2C(C)C=CC3=CCCC(OC(=O)C(C)CC)C32C)O1</smiles>

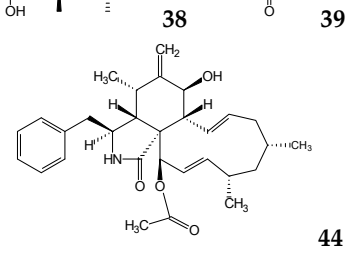<smiles>COc1cccc2oc3c(Cl)c4c(c(O)c3c(=O)c12)[C@H]1CCC[C@](C)(O4)O1</smiles><smiles>COc1cccc2oc3c(Cl)c(O)c(C4CCCC(C)O4)c(O)c3c(=O)c12</smiles>

55<smiles>O=c1cc(CO)occ1O</smiles>

52<smiles>COc1cccc2oc3c(Cl)c4c(c(O)c3c(=O)c12)[C@H]1CC(O)CC(C)(O4)O1</smiles><smiles>CCCCCCCc1c(O)cc(CC=C(C)C)c(O)c1C=O</smiles><smiles>CCCC=Cc1cc2c(CO)c(O)c(CC=C(C)C)cc2o1</smiles>

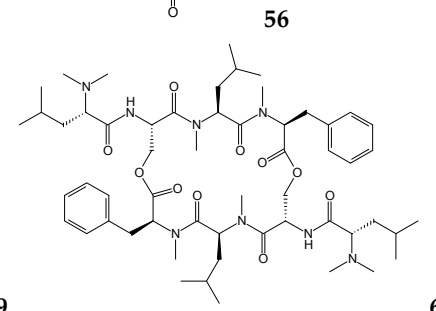<smiles>O=Cc1cc(O)ccc1O</smiles><smiles>COc1cc(=O)oc(C)c1C(=O)CC(C)O</smiles><smiles>COc1cc(=O)oc(C)c1/C=C/C(C)O</smiles><smiles>COc1cc(=O)oc(/C=C/C=C/C=C/C(C)=C/[C@H]2O[C@H](C)C(C)(O)[C@H]2O)c1C</smiles><smiles>O=C1O[C@H](Cc2ccccc2)CC1O</smiles>

Figure 2. Chemical structures of fungal metabolites with antitrypanosomatid activity. 
Hypocrellin A (31) and hypocrellin B (32), perylene quinonoid pigments isolated from fungus Hypocrella bambusae, exhibited antileishmanial activity. Hypocrellin A showed significant antileishmanial activity against promastigotes of L. donovani $\left(\mathrm{IC}_{50}=0.5 \mu \mathrm{M}\right)$, while B was moderately active with an $\mathrm{IC}_{50}$ of $24 \mu \mathrm{M}$. Interestingly, the antileishmanial activity of hypocrellin A was three- and sixfold more potent than that of amphotericin B and pentamidine, respectively [78].

Endophytes are microorganisms, including bacteria or fungi, which live within apparently healthy host plant tissues without causing observable manifestations of the disease. Endophytic microbes have been recognized as essential sources of structurally new and biologically active secondary metabolites [79]. The polyketide citrinin (33), produced for an endophytic fungus Penicillium janthinellum, isolated from fruits of Melia azedarach (Meliaceae), presented $100 \%$ activity against promastigotes of L. mexicana after $48 \mathrm{~h}$ at a concentration of $160 \mu \mathrm{M}$ [80].

Among several endophytic fungi isolated from Trixis vauthieri (Asteraceae) leaves, Alternaria sp. produced a biphenyl phenolic compound, called altenusin (34), that demonstrated inhibitory activity against the enzyme trypanothione reductase (TR) from T. cruzi at an $\mathrm{IC}_{50}$ of $4.3 \mu \mathrm{M}$. This enzyme is a validated drug target in trypanosomatids as it was shown to be essential for the survival of these parasites, protecting them against oxidative stress [81]. However, this inhibitory activity did not translate into the decreased viability of amastigote-like forms of L. amazonensis, probably because altenusin did not reach the intracellular compartments where TR is located [82].

In another study, two new perylenequinones were isolated from Alternaria sp. (DC401), an endophytic fungus isolated from Pinus ponderosa (Pinaceae). These compounds were tested for their in vitro antileishmanial potential, where 3,6,6a,9,10-pentahydroxy-7,8epoxy-4-oxo-4,5,6,6a,6b,7,8,9-octahydroperylene (35) and 3,6,6a,7,10-pentahydroxy-4,9dioxo-4,5,6,6a,6b,7,8,9-octahydroperylene (36) showed antileishmanial activity against L. donovani promastigotes with $\mathrm{IC}_{50}$ values of 7 and $12 \mu \mathrm{M}$, respectively. However, 36 exhibited cytotoxicity activity against Vero cells with an $\mathrm{IC}_{50}$ of $10 \mu \mathrm{M}$ [83].

The endophytic fungus, Cochliobolus sp., isolated from Piptadenia adiantoides (Fabaceae), produced two quinonoid compounds, cochlioquinone A (37) and isocochlioquinone A (38). Both compounds showed antileishmanial activity against axenic amastigotes of L. amazonensis, with $\mathrm{EC}_{50}$ values of 1.7 and $4.1 \mu \mathrm{M}$, respectively. These compounds were not active against three human cancer cell lines (MCF-7, TK-10, and UACC-62), indicating some degree of selectivity towards the parasites. However, these metabolites were not active against trypanothione reductase (TR) from T. cruzi [84].

From Edenia sp., a fungus isolated from a mature leaf of Petrea volubilis (Verbenaceae), bisnaphthospiroketal-containing antileishmanial compounds were purified. Preussomerin EG1 (39) $\left(\mathrm{IC}_{50}=0.12 \mu \mathrm{M}\right)$ was the most active and inhibited growth of $L$. donovani axenic amastigotes with a similar potency to amphotericin $\mathrm{B}\left(\mathrm{IC}_{50}=0.1 \mu \mathrm{M}\right)$. This compound showed marked cytotoxicity to mammalian Vero cells $\left(\mathrm{IC}_{50}=9 \mu \mathrm{M}\right)$, although it was 75-fold more active against $L$. donovani. Palmarumycin $\mathrm{CP}_{17}(40)(1.34 \mu \mathrm{M})$ and palmarumycin $\mathrm{CP}_{18}(41)(0.62 \mu \mathrm{M})$ were less active than preussomerin EG1, but they also showed less cytotoxicity to mammalian Vero cells, thus giving therapeutic indexes of 130 and 245, respectively [85]. Furthermore, palmarumycin $\mathrm{CP}_{18}$ showed antileishmanial activity against L. donovani amastigotes in periperitoneal macrophage (Balb/c mice), with $\mathrm{IC}_{50}$ values of $23.5 \mu \mathrm{M}$ [86].

The marine endophytic fungus Ascochyta salicorniae, isolated from the green alga Ulva sp., produced a pyrrole alkaloid, ascosalipyrrolidinone A (42). This metabolite exhibited significant activity against $T$. cruzi at a minimum inhibitory concentration (MIC) of $2.6 \mu \mathrm{M}$ and against T. $b$. rhodesiense at a MIC of $70.1 \mu \mathrm{M}$, as well as having cytotoxic activity against rat skeletal muscle myoblast cells (MIC $=8.65 \mu \mathrm{M}$ ) and mouse peritoneal macrophages $(\mathrm{MIC}=5.1 \mu \mathrm{M})$. Additionally, the furanic metabolite isolated from A. salicorniae, 2,3-dihydro2-hydroxy-2,4-dimethyl-5-trans-propenylfuran-3-one (43), exhibited activity against $T . b$. 
rhodesiense and T. cruzi at MIC values of 178 and $535 \mu \mathrm{M}$, but it was more cytotoxic to L-6 cells $(\mathrm{MIC}=59.4 \mu \mathrm{M})$ [87].

Compound 18-des-hydroxy cytochalasin $\mathrm{H}$ (44) produced by the endophytic fungus Diaporthe phaseolorum-92C, isolated from the roots of Combretum lanceolatum (Combretaceae), reduced the viability of $L$. amazonensis promastigotes, $\mathrm{IC}_{50}=19.2 \mu \mathrm{M}$, and of the cancer cells MDA-MB-231 and MCF-7 with $\mathrm{IC}_{50}$ values of 36.5 and $18.3 \mu \mathrm{M}$, respectively, and gave an $\mathrm{IC}_{50}$ of $428 \mu \mathrm{M}$ for the cytotoxicity towards normal cells GM07492A [88].

A screening of 82 endophytic fungi from stems and barks of Caesalpinia echinata Lam. (Fabaceae) resulted in the isolation of Fusarium sp. KF611679, which produced a depsipeptide called beauvericin (45) with activity against $T$. cruzi amastigotes with an $\mathrm{IC}_{50}$ of $2.43 \mu \mathrm{M}$, and an $\mathrm{IC}_{50}$ of $6.38 \mu \mathrm{M}$ against the mouse L929 fibroblasts [89]. The endophytic fungus Nectria pseudotrichia, also isolated from the tree C. echinata, biosynthesized active metabolites against intracellular amastigote forms of L. braziliensis expressing firefly luciferase. Compounds, 10-acetyl trichoderonic acid A (46), 6'-acetoxy-piliformic acid (47), and hydroheptelidic acid (48) were more active, with $\mathrm{IC}_{50}$ values of $21.4,28.3$, and $24.8 \mu \mathrm{M}$, respectively, and showed low toxicity to Vero and THP-1 cells [90].

Two endophytic strains isolated from Handroanthus impetiginosus (Bignoniaceae) leaves, identified as Talaromyces purpurogenus H4 and Phanerochaete sp. H2 (Basidiomycete) were grown in mixed and axenic cultures. The meroterpenoid austin (49) was detected only in the extracts from the mixed culture. This metabolite had an $\mathrm{IC}_{50}$ of $73.1 \mu \mathrm{M}$ against epimastigotes of $T$. cruzi and a $50 \%$ cytotoxic concentration $\left(\mathrm{CC}_{50}\right)$ of $351 \mu \mathrm{M}$ on $\mathrm{H} 9 \mathrm{c} 2$ cells, so it had a selectivity index of 4.8 [91].

Ascofuranone (50), a meroterpenoid produced by several filamentous fungi, including Acremonium egyptiacum (synonym: Acremonium sclerotigenum), which has been known as Ascochyta vicia [92,93], specifically inhibited the ubiquinol oxidase activity of trypanosoma mitochondrial (AOX or TAO) at an $\mathrm{IC}_{50}$ of $0.13 \mathrm{nM}[93,94]$. Additionally, ascofuranone showed therapeutic efficacy against T. b. brucei infection in mice at $100 \mathrm{mg} / \mathrm{kg} /$ day intraperitoneally for four consecutive days and $400 \mathrm{mg} / \mathrm{kg} /$ day for eight days orally. It was also determined that TAO activity decreased by 30\% [95]. Since T. brucei parasites rely exclusively on glycolysis as an energy source in the mammalian bloodstream using TAO to reoxidize NADH and mammalian hosts lack this protein, this enzyme is considered a key target for the generation of antitrypanosomal drugs [96]. The structure-activity relationship analysis of ascofuranone demonstrated that 1-formyl and 6-hydroxyl groups are responsible for the interaction with the enzyme, and 2-methyl and/or 3-chloro groups contribute to proper conformation, while the furanone ring is not essential for activity [94]. However, its stereoselective synthesis is complex, and, therefore, a bioengineering strategy has recently been proposed to benefit combinatorial biosynthesis through biocatalysts [92,97].

Mycophenolic acid (51) produced by several Penicillium species showed inhibitory activity against the inosine $5^{\prime}$-monophosphate dehydrogenase (IMPDH) of T. brucei at a Ki value of $21 \mathrm{nM} \mathrm{[98].} \mathrm{Mycophenolic} \mathrm{acid} \mathrm{also} \mathrm{demonstrated} \mathrm{an} \mathrm{inhibition} \mathrm{rate} \mathrm{against}$ T. congolense $(99.60 \%)$, T. b. brucei $(82.99 \%)$, and T. evansi $(90.53 \%)$ at a concentration of $1 \mu \mathrm{M}$, showing that it inhibited the IMPDH of T. congolense [99]. This enzyme is crucial in Trypanosoma spp. because it lacks a de novo purine synthesis pathway, making purine nucleotide synthesis in these parasites solely dependent on a salvage pathway [99]. Finally, a recent study showed activity against $T$. b. brucei at an $\mathrm{IC}_{50}$ of $0.51 \mu \mathrm{M}$ and T. cruzi intracellular amastigotes at an $\mathrm{IC}_{50}$ of $1.6 \mu \mathrm{M}$, but it exhibited cytotoxic activity against macrophages [100].

Mevastatin (52), the first statin isolated from Penicillum citrinum [101], was active against promastigotes and intracellular amastigotes of Leishmania donovani with $\mathrm{IC}_{50}$ values of 23.8 and $7.5 \mu \mathrm{M}$, respectively, without showing toxicity to the THP-1 macrophages. Mevastatin-treated parasites showed a $66 \%$ reduction in ergosterol levels and it also induced morphological changes in the parasites accompanied by lipid body accumulation. Therefore, its antileishmanial effect was due to the inhibition of 3-hydroxy-3-methyl 
glutaryl-CoA reductase (HMGR), which eventually leads to a reduction in ergosterol levels and parasites death [102].

Xanthones represent a structurally diverse group of natural products with a broad range of biological activities. Several derived xanthones were isolated from higher plants, lichens, and fungi and possess promising antiprotozoal activities, but they also showed pronounced cytotoxicity, making them problematic for pharmaceutical use. Investigations of the marine-derived fungus Chaetomium sp. yielded three new xanthones, called chaetoxanthones A (53), B (54), and C (55), with unusual and rare structural features for this structural class of natural products. Compound A was active against trypomastigotes of T. b. rhodesiense at an $\mathrm{IC}_{50}$ of $12.6 \mu \mathrm{M}$, whereas compound $\mathrm{C}$ inhibited the growth of $T$. cruzi amastigotes with an $\mathrm{IC}_{50}$ value of $3.83 \mu \mathrm{M}$. Xanthones $\mathrm{B}$ and $\mathrm{C}$ showed leishmanicidal effects toward amastigotes of $L$. donovani with $\mathrm{IC}_{50}$ values of 9.6 and $8 \mu \mathrm{M}$, respectively, and only low cytotoxicity for compound $\mathrm{C}\left(\mathrm{IC}_{50}=119 \mu \mathrm{M}\right)$ and no observed cytotoxic effects for compound B up to $254 \mu \mathrm{M}$ [103].

Kojic acid (56) (KA) is a fungal metabolic product produced by a few species of Aspergillus, especially by A. oryzae, as a by-product in the fermentation process of malting rice [104], and it is widely used in cosmetics as a UV protector, hyperpigmentation suppressant and limiter of melanin formation [105]. In a study in vitro on promastigotes and amastigotes of L. amazonensis, KA exhibited an $\mathrm{IC}_{50}$ of $239 \mu \mathrm{M}$ against promastigotes and an $\mathrm{IC}_{50}$ of $193 \mu \mathrm{M}$ against amastigotes. Ultrastructural analysis of KA-treated amastigotes showed vesicle body presence in the flagellar pocket and an intense intracellular vacuolization and swelling of the mitochondrion. Additionally, it was observed that, after four weeks of treatment with KA ( $100 \mathrm{mg} / \mathrm{kg} /$ day) to infected Golden hamsters, collagen fiber production was increased, and the parasitic burden was drastically reduced [106]. In another study, it was demonstrated that KA promotes monocytes' differentiation into macrophages and acts as an immunomodulator [107].

Filamentous fungus Geosmithia langdonii cultivated in potato dextrose broth, produced seven active compounds against $L$. donovani promastigotes, whose $\mathrm{IC}_{50}$ values ranged from 3.3 to $47.3 \mu \mathrm{M}$. In particular, 2,5-dihydroxybenzaldehyde (57) was the most active and had an antiprotozoal activity very similar to the positive control, pentamidine, which presented an $\mathrm{IC}_{50}$ of $3.2 \mu \mathrm{M}$ [108]. Additionally, other metabolites produced by this fungus have been reported, such as carbasugar-type and diarylmethane compounds with activity against L. donovani $[109,110]$.

The fungus Eurotium repens produced eight benzyl derivatives that were tested in vitro against $L$. donovani promastigotes. Six of them presented antiprotozoal activity with IC 50 values ranging from 20.7 to $75.5 \mu \mathrm{M}$, with auroglaucin (58) and 2-(2',3-epoxy-1', $3^{\prime}$ heptadienyl)-6-hydroxy-5-(3-methyl-2-butenyl)benzaldehyde (59) being the most active with $\mathrm{IC}_{50}$ values of 25 and $20.7 \mu \mathrm{M}$, respectively. These metabolites did not show cytotoxic activity to Vero cells [111].

IB-01212 (60), an antitumoral depsipeptide isolated from the mycelium of the marine fungus Clonostachys sp., has been shown to have leishmanicidal activity against $L$. donovani promastigote and L. pifanoi amastigote forms at $\mathrm{LC}_{50}$ values of 10.5 and $7.1 \mu \mathrm{M}$, respectively. This compound induces an apoptosis-like process without significant permeabilization of the plasma membrane, thereby suggesting an intracellular target associated with the depolarization of the mitochondrial electrochemical gradient. The evaluation of its synthetic analogs established that the cycle's size, the preservation of the C-2 symmetry, and the nature of the bonds linking the two tetrapeptide halves participate in modulating the leishmanicidal activity [112].

Pyrenocines A (61), B (62), I (63), and citreoviridin (64) were isolated from the culture broth of Paecilomyces sp. FKI-3573. All compounds exhibited in vitro antitrypanosomal activity using GUTat 3.1 strain of T. b. brucei and slightly more selective activity towards parasites than MRC-5 cells. However, citreoviridin $\left(\mathrm{IC}_{50}=1.2 \mu \mathrm{M}\right)$ was the compound that showed the best selective index of 94 . Since citreoviridin inhibited the mitochondrial F1-ATPase of T. cruzi and the structural similarity of this compound and pyrenocines, it 
was suggested that pyrenocines might perform their antitrypanosomal activity through a similar mode of action [113]. Finally, Paecilomyces sp. 7A22, a marine-derived fungus, excreteda polyketide called harzialactone A (65) in the culture medium. This metabolite showed activity against $L$. amazonesis promastigotes and intracellular amastigotes with $\mathrm{IC}_{50}$ values of 27.3 and $94.6 \mu \mathrm{M}$, respectively [114].

\section{Future Microbial Metabolites}

Microorganisms are promising resources for producing bioactive compounds, considering some of the advantages attributed to them, such as rapid and adaptable cultures and even the possibility of genetic manipulation. In the search for new biologically active molecules, research work has been extended to analyze microorganisms found in less explored environments. An example of this is the current trend of studying the microbiota of the vectors that transmit trypanosomatid diseases with the possible purposes of carrying out biological control or detecting antiprotozoal compounds [115]. Enterobacter cloacae, isolated from the digestive tract of Lutzomyia evasi (Leishmania vector), inhibited by $72.29 \%$ the growth of procyclic-like promastigotes when co-cultured under in vitro conditions. This study suggested that E. clocae generated peptides or molecules with cytolysin-like activity [115]. More recently, the methanolic extract of Enterobacter hormaechei, isolated from the intestine of Lu. evasi, showed toxic activity against promastigotes of L. braziliensis (UA301 strain) [116]. Studies into the vector microbiota of American and African Trypanosomiasis, triatomines and the tsetse fly, have been performed, but not yet with this objective; however, this may be a good strategy for finding new active compounds.

Marine ecosystems are complex and often harbor very diverse marine organisms. In this environment, there is intense competition for survival and environmental pressure, such as high salt content, high pressure, low temperature, oligotrophic characteristics, and lightless or high levels of solar radiation $[9,117]$. This biodiversity uses metabolites for defense, attack, or signaling [9]. These metabolites will continue to be a constant source of new chemical structures to be evaluated for potential therapeutic use, in their original form or after chemical optimization [118]. Currently, the study of culturable microbiota present in marine sediments at different depths and in ice fragments collected in Antarctica has shown that species of the genus Penicillum have preliminary activity against L. amazonensis promastigotes and T. cruzi trypomastigotes and amastigotes in L929 fibroblasts. Additionally, the ${ }^{1} \mathrm{H}-\mathrm{NMR}$ analysis determined the presence of aromatic compounds and terpenoids $[119,120]$.

Another source of bioactive metabolites is endophytic microorganisms. Recent studies have shown that several fungal species produce metabolites with antiprotozoal activity, but very little has been reported about endophytic bacteria [121]. In this case, the isolation of endophytic bacteria from Fagonia indica (Zygophyllaceae) showed Bacillus, Enterobacter, Pantoea, Erwinia, and Stenotrophomonas species that exhibited preliminary activity against Leishmania tropica promastigotes [122].

However, drug discovery based on natural products presents a considerable challenge due to the large amount of resources and tedious purification protocols involved in identifying bioactive molecules from the highly complex mixtures that are the initial extracts. When purified, the isolated bioactive compound is often obtained in small quantities that are unlikely to span the entire drug discovery process [123]. Furthermore, there is controversy in evaluating these metabolites in a phenotypic or a target-based assay, although they are complementary, and both have their pros and cons [124].

In the phenotypic assay, it is necessary to use the most relevant form of the pathogenic parasite. In HAT, the bloodstream forms of T. brucei are accessible to culture under in vitro conditions that can closely resemble the blood environment where the parasite lives. However, this is not easy to reproduce with T. cruzi, as it has an early trypomastigote form in the bloodstream that rapidly invades different host cells and transforms into intracellular amastigotes. In contrast, in Leishmania spp., the most relevant pathological form is the amastigote that lives within the phagolysosomes of host macrophages, so compounds must 
cross multiple membranes to reach the parasite in cellular assays $[9,124]$. However, many compounds have been evaluated in forms of the free-living parasites, such as promastigotes and trypomastigotes, or axenic amastigotes, an unnatural extracellular form created under laboratory conditions, that can detect very preliminary antiprotozoal activity or simple cytotoxicity (Table 1) [9]. Therefore, it is necessary to culture mammalian cells infected in vitro with the pathogen, and, thus, the toxicity of the drug towards cells and its ability to be selective towards the parasites is known [125]. However, after a drug has demonstrated potential antiparasitic activity, its mechanism of action must be known, so target-based assays are indispensable.

Table 1. Microorganisms and their antiprotozoal metabolites.

\begin{tabular}{|c|c|c|c|c|}
\hline Microbial Species & Metabolite(s) & Target Parasite & $\mathrm{IC}_{50}(\mu \mathrm{M})$ & Ref. \\
\hline \multicolumn{5}{|c|}{ Bacteria } \\
\hline \multicolumn{5}{|c|}{ Actinobacteria } \\
\hline Micromonospora sp. & Manzamine A & L. donovani ${ }^{\text {a }}$ & 1.63 & {$[41,42]$} \\
\hline Micromonospora sp. & Lobosamide A & T. b. brucei ${ }^{\mathrm{b}}$ & 0.80 & [44] \\
\hline Streptomyces sp. & Valinomycin & $\begin{array}{l}{\text { L. } \text { major }^{\mathrm{a}}} \\
\text { T. b. } \text { brucei }^{\mathrm{b}}\end{array}$ & $\begin{array}{c}<0.11 \\
0.0032\end{array}$ & [45] \\
\hline Streptomyces axinellae & Tetromycin 1 & T.b. brucei ${ }^{\mathrm{b}}$ & 31.7 & [46] \\
\hline $\begin{array}{l}\text { Streptomyces sp. } \\
\text { ICBG292 }\end{array}$ & Nigericin & L. donovani ${ }^{\mathrm{a}, \mathrm{c}}$ & $\begin{array}{l}0.28^{a} \\
0.13^{c}\end{array}$ & [48] \\
\hline Streptomyces sp. ICBG233 & Dinactin & L. donovani ${ }^{\mathrm{a}, \mathrm{c}}$ & $\begin{array}{l}0.03^{\mathrm{a}} \\
0.02^{\mathrm{c}}\end{array}$ & [48] \\
\hline Streptomyces diastatochromogenes & Oligomycin & $\begin{array}{l}\text { T. brucei }{ }^{\mathrm{b}} \\
\text { T. } \text { cruzi }^{\mathrm{c}}\end{array}$ & $\begin{array}{c}3.8 \\
0.52\end{array}$ & {$[50,53]$} \\
\hline Streptomyces chartreusensis & Calcimycin & $\begin{array}{l}\text { L.enriettii }{ }^{\mathrm{c}} \\
\text { L. major }\end{array}$ & $\begin{array}{l}0.01-0.25 \\
0.16\end{array}$ & {$[56,58]$} \\
\hline $\begin{array}{c}\text { Actinokineospora sp. EG49 and } \\
\text { Nocardiopsis } \\
\text { sp. RV163 }\end{array}$ & 1,6-dihydroxyphe-nazine & T. brucei ${ }^{\mathrm{b}}$ & 19 & [59] \\
\hline Actinokineospora sp. EG49 & Actinosporin A & T.b. brucei ${ }^{\mathrm{b}}$ & 15 & {$[60]$} \\
\hline Actinokineosporaspheciospongiae & Fridamycin $\mathrm{H}$ & T. brucei ${ }^{\mathrm{b}}$ & $\begin{array}{l}7.18^{\mathrm{e}} \\
3.35^{\mathrm{f}}\end{array}$ & [61] \\
\hline \multicolumn{5}{|c|}{ Cyanobateria } \\
\hline Symploca sp. & Symplocamide A & $\begin{array}{l}\text { L. donovani }{ }^{\mathrm{d}} \\
\text { T. } \text { cruzi }^{\mathrm{c}}\end{array}$ & $\begin{array}{l}>9.5 \\
>9.5\end{array}$ & [62] \\
\hline Oscillatoria sp. & $\begin{array}{l}\text { Venturamide A } \\
\text { Venturamide B }\end{array}$ & T. cruzi ${ }^{\mathrm{c}}$ & $\begin{array}{l}14.6 \\
15.8\end{array}$ & [63] \\
\hline Oscillatoria nigro-viridis & Viridamine A & $\begin{array}{l}\text { L. mexicana } \\
\text { T. } \text { cruzi }^{\mathrm{d}}\end{array}$ & $\begin{array}{l}1.5 \\
1.1\end{array}$ & [64] \\
\hline Oscillatoria sp. & Coibacin A & L. donovani $\mathrm{d}$ & 2.4 & {$[65]$} \\
\hline Lyngbya majuscula & $\begin{array}{c}\text { Dragonamide A } \\
\text { Dragonamide E } \\
\text { Herbamide B } \\
\text { Almiramide B } \\
\text { Almiramide C }\end{array}$ & L. donovani ${ }^{\mathrm{d}}$ & $\begin{array}{c}6.5 \\
5.1 \\
6 \\
2.4 \\
2\end{array}$ & $\begin{array}{c}{[66]} \\
{[67,68]}\end{array}$ \\
\hline Schizothrix sp. & Gallinamide A & L. donovani ${ }^{\mathrm{d}}$ & 9.3 & [69] \\
\hline
\end{tabular}


Table 1. Cont.

\begin{tabular}{|c|c|c|c|c|}
\hline Microbial Species & Metabolite(s) & Target Parasite & $\mathrm{IC}_{50}(\mu \mathrm{M})$ & Ref. \\
\hline \multicolumn{5}{|c|}{ Cyanobateria } \\
\hline Nostoc78-12A & Nostocarboline & L. donovani ${ }^{\mathrm{d}}$ & 34.3 & [70] \\
\hline Okenia sp. & Janadolide & $\begin{array}{c}\text { T. } \text { brucei }^{\mathrm{b}} \\
\text { T.b. } \text { rhodesiense }^{\mathrm{b}} \\
\text { T. } \text { cruzi }^{\mathrm{c}}\end{array}$ & $\begin{array}{c}0.047 \\
91.3 \\
69.3\end{array}$ & {$[71,73]$} \\
\hline \multicolumn{5}{|c|}{ Firmicutes } \\
\hline Bacillus pumilus & $\begin{array}{c}\text { 3-hydroxyacetyl-indole } \\
N \text {-acetyl- } \beta \text {-oxotrypta-mine } \\
\text { 3-formylindole }\end{array}$ & T. cruzi ${ }^{\mathrm{c}}$ & $\begin{array}{c}20.6 \\
19.4 \\
27\end{array}$ & [74] \\
\hline \multicolumn{5}{|c|}{ Gammaproteobacteria } \\
\hline Pseudomonas sp. & $\begin{array}{l}\text { Pseudopyronine A } \\
\text { Pseudopyronine B }\end{array}$ & L. donovani $\mathrm{d}$ & $\begin{array}{c}9.8 \\
4.65\end{array}$ & [75] \\
\hline \multicolumn{5}{|c|}{ Fungi } \\
\hline \multicolumn{5}{|c|}{ Ascomycetes } \\
\hline Nigrospora sphaerica & Aphidicolin & $\begin{array}{l}\text { L. donovani }{ }^{\mathrm{a}} \\
\text { L. infantum }^{\mathrm{a}} \\
\text { L. enriettii }^{\mathrm{a}} \\
\text { L. major }^{\mathrm{a}} \\
\text { L. donovani } \\
\text { d }\end{array}$ & $\begin{array}{c}157 \\
40.8 \\
90.4 \\
55.4 \\
35 \\
\end{array}$ & {$[76,77]$} \\
\hline Hypocrella bambusae & $\begin{array}{l}\text { Hypocrellin A } \\
\text { Hypocrellin B }\end{array}$ & L. donovani ${ }^{\mathrm{a}}$ & $\begin{array}{l}0.5 \\
24\end{array}$ & [78] \\
\hline Penicillium janthinellum & Citrinin & L. mexicana ${ }^{\mathrm{a}}$ & $160^{\mathrm{e}, 1}$ & [80] \\
\hline Alternaria sp. & Altenusin & T. cruzi $\mathrm{g}$ & 4.3 & [82] \\
\hline Alternaria sp. (DC401) & $\begin{array}{c}\text { 3,6a,9,10-pentahydroxy-7,8- } \\
\text { epoxy-4-oxo- } \\
\text { 4,5,6,6a,6b,7,8,9-octahydro- } \\
\text { perylene } \\
3,6,6 \mathrm{a}, 7,10-\text { pentahdroxy-4,9- } \\
\text { dioxo- } 4,5,6,6 \mathrm{a}, 6 \mathrm{~b}, 7,8,9- \\
\text { octahydro-perylene }\end{array}$ & L. donovani ${ }^{\mathrm{a}}$ & $\begin{array}{c}7 \\
12\end{array}$ & [83] \\
\hline Cochliobolus sp. & $\begin{array}{l}\text { Cochlioquinone A } \\
\text { Isocochlioquinone A }\end{array}$ & L. amazonensis $\mathrm{d}$ & $\begin{array}{l}1.7 \\
4.1 \\
\end{array}$ & {$[84]$} \\
\hline Edenia sp. & $\begin{array}{l}\text { Preussomerin EG1 } \\
\text { Palmarumycin } \mathrm{CP}_{17} \\
\text { Palmarumycin } \mathrm{CP}_{18}\end{array}$ & L. donovani ${ }^{\mathrm{c}, \mathrm{d}}$ & $\begin{array}{l}0.12^{\mathrm{d}} \\
1.34^{\mathrm{d}} \\
0.62^{\mathrm{d}} \\
23.5^{\mathrm{c}}\end{array}$ & {$[85,86]$} \\
\hline Ascochyta salicorniae & $\begin{array}{l}\text { Ascosalipyrrolidinone A } \\
\text { 2,3-dihydro-2-hydroxy-2,4- } \\
\text { dimethyl-5-trans- } \\
\text { propenylfuran-3-one }\end{array}$ & $\begin{array}{l}\text { T. } \text { cruzi }^{\mathrm{a}} \\
\text { T.b. rhodesiense }\end{array}$ & $\begin{array}{l}2.6^{\mathrm{h}} \\
70.1^{\mathrm{h}} \\
535^{\mathrm{h}} \\
178^{\mathrm{h}}\end{array}$ & [87] \\
\hline Diaporthe phaseolorum-92C & $\begin{array}{c}\text { 18-des-hydroxy cytochalasin } \\
\mathrm{H}\end{array}$ & L. amazonensis ${ }^{a}$ & 19.2 & [88] \\
\hline Fusarium sp. KF611679 & Beauvericin & T. cruzi ${ }^{\text {c }}$ & 2.43 & [89] \\
\hline Nectria pseudotrichia & $\begin{array}{c}\text { 10-acetyl trichoderonic acid } \\
\text { A } \\
\text { 6'-acetoxy-piliformic acid } \\
\text { Hydroheptelidic acid }\end{array}$ & L. braziliensis ${ }^{\mathrm{c}}$ & $\begin{array}{l}21.4 \\
28.3 \\
24.8\end{array}$ & {$[90]$} \\
\hline
\end{tabular}


Table 1. Cont.

\begin{tabular}{|c|c|c|c|c|}
\hline Microbial Species & Metabolite(s) & Target Parasite & $\mathrm{IC}_{50}(\mu \mathrm{M})$ & Ref. \\
\hline \multicolumn{5}{|c|}{ Ascomycetes } \\
\hline Talaromycespurpurogenus H4 & Austin & T.cruzi $i^{\mathrm{i}}$ & 73.1 & [91] \\
\hline Acremonium egyptiacum & Ascofuranone & T. b. brucei $\mathrm{j}$ & 0.00013 & [93] \\
\hline Penicillium sp. & Mycophenolic acid & 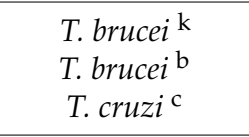 & $\begin{array}{c}0.021 \\
0.51 \\
1.6\end{array}$ & {$[99,100]$} \\
\hline Penicillum citrinum & Mevastatin & L. donovani ${ }^{\mathrm{a}, \mathrm{c}}$ & $\begin{array}{l}23.8^{\mathrm{a}} \\
7.5^{\mathrm{c}}\end{array}$ & [102] \\
\hline Chaetomium sp. & $\begin{array}{l}\text { Chaetoxanthone A } \\
\text { Chaetoxanthone B } \\
\text { Chaetoxanthone C }\end{array}$ & $\begin{array}{c}\text { T. b. rhodesiense } \mathrm{b} \\
\text { L. donovani }^{\mathrm{c}} \\
\text { T. } \text { cruzi }^{\mathrm{c}} \\
\text { L. donovani } \\
\text { c }\end{array}$ & $\begin{array}{c}12.6 \\
9.6 \\
3.83 \\
8\end{array}$ & [103] \\
\hline Aspergillus oryzae & Kojic acid & L. amazonensis ${ }^{\mathrm{a}, \mathrm{c}}$ & $\begin{array}{l}239^{a} \\
193^{c}\end{array}$ & [106] \\
\hline Geosmithia langdonii & 2,5-dihydroxybenzaldehyde & L. donovani ${ }^{\text {a }}$ & 3.3 & [108] \\
\hline Eurotium repens & $\begin{array}{c}\text { Auroglaucin } \\
\text { 2-(20,3-epoxy-10,30- } \\
\text { heptadienyl)-6-hydroxy-5-(3- } \\
\text { methyl-2- } \\
\text { butenyl)benzaldehyde }\end{array}$ & L. donovani ${ }^{\text {a }}$ & $\begin{array}{c}25 \\
20.7\end{array}$ & [111] \\
\hline Clonostachys sp. & IB-01212 & $\begin{array}{l}\text { L. donovani }{ }^{\mathrm{a}} \\
\text { L. pifanoi }^{\mathrm{c}}\end{array}$ & $\begin{array}{l}10.5 \\
7.1\end{array}$ & [112] \\
\hline Paecilomyces sp. FKI-3573 & $\begin{array}{l}\text { Pyrenocines A } \\
\text { Pyrenocine B } \\
\text { Pyrenocine I } \\
\text { Citreoviridin }\end{array}$ & T.b. brucei ${ }^{\mathrm{b}}$ & $\begin{array}{c}0.57 \\
3.35 \\
8.56 \\
1.2\end{array}$ & [113] \\
\hline Paecilomyces sp. 7A22 & Harzialactone A & L. amazonensis ${ }^{\mathrm{a}, \mathrm{c}}$ & $\begin{array}{l}27.3^{a} \\
94.6^{c}\end{array}$ & [114] \\
\hline \multicolumn{5}{|c|}{ Basidiomycetes } \\
\hline Phanerochaete sp. H2 & Austin & T. cruzi ${ }^{\mathrm{i}}$ & 73.1 & [91] \\
\hline
\end{tabular}

${ }^{a}$ promastigotes; ${ }^{\mathrm{b}}$ trypomastigotes; ${ }^{\mathrm{c}}$ intracellular amastigotes; ${ }^{\mathrm{d}}$ axenic amastigotes; ${ }^{\mathrm{e}} \mathrm{IC}_{50}(48 \mathrm{~h}) ;{ }^{\mathrm{f}} \mathrm{IC}_{50}(72 \mathrm{~h}) ;{ }^{\mathrm{g}}$ trypanothione reductase; ${ }^{\mathrm{h}}$ minimum inhibitory concentration; ${ }^{\mathrm{i}}$ epimastiogtes; ${ }^{\mathrm{j}}$ ubiquinol oxidase; ${ }^{\mathrm{k}}$ inosine $5^{\prime}$ monophosphate dehydrogenase; ${ }^{\mathrm{l}} 100 \%$ activity.

In a target-based assay, it is established that if a validated drug target and an excellent chemical scaffold interact, a rational structure-based drug discovery approach can be adapted for the synthesis of thousands of new compounds in the search for drug candidates [9]. For neglected diseases in general, including trypanosomatid diseases, the success of target-based approaches has been minimal. In part, this reflects the absence of robustly validated targets, enzymes whose activity is essential for the parasite [124].

This is complicated by the presence of reactive compounds with multiple assay behavior, such as covalent bond formation, chelation, membrane perturbation, and redox activity, which are collectively known as Pan Assay Interfering Compounds (PAINS) [126]. Natural products that frequently contain PAINS include catechols, quinones, phenolic mannich bases, and hydroxyphenylhydrazones [127]. Despite a possible nano- or micromolar potency, PAINS lack a distinct biological mechanism, exhibit poor SAR or optimizing ability and, therefore, have minimal prospect for clinical development. Therefore, it is crucial to use assay techniques that eliminate PAINS and perform structural studies of hit binding to its target and structure-activity optimization studies of hits [128].

Finally, the search for new drugs against infectious diseases caused by trypanosomatids, considering the criteria proposed by the Drugs for Neglected Diseases initiative (DNDi) and the Global Health Innovative Technology (GHIT) Fund for hits com- 
pounds [129], should ideally have a potency that can be improved to generate a lead compound with the absence of highly reactive functional groups that could cause nonspecific or false-positive results. Regarding its activity, it is recommended that a hit exhibits at least an $\mathrm{IC}_{50}$ value $<10 \mu \mathrm{M}$ from phenotypic assays and a tenfold selectivity toward parasite cells over host organism cells. The cost of production is an essential variable. Therefore, the synthetic route should be as simple as possible (ideally five steps or less) with acceptable yields [129].

Author Contributions: M.J.C.-B. designed the format of paper, wrote the manuscript and drew the structures of the compounds; M.M.R.-E. reviewed the manuscript and designed the table; J.C.C.-C. and B.O.O.-M. reviewed the manuscript and designed part of the format of paper. All authors have read and agreed to the published version of the manuscript.

Funding: This research received no external funding.

Institutional Review Board Statement: Not applicable.

Informed Consent Statement: Not applicable.

Acknowledgments: The authors are grateful to the teacher Ruth E. Tun Beltrán for her help with the English edition and Luis Manuel Peña-Rodríguez for his suggestions.

Conflicts of Interest: The authors declare no conflict of interest.

\section{References}

1. Scotti, M.T.; Scotti, L.; Ishiki, H.; Ribeiro, F.F.; Cruz, R.M.; Oliveira, M.P.; Mendonça, F.J. Natural products as a source for antileishmanial and antitrypanosomal Agents. Comb. Chem. High Throughput Screen 2016, 19, 537-553. [CrossRef] [PubMed]

2. Werbovetz, K.A. Target-based drug discovery for malaria, leishmaniasis, and trypanosomiasis. Curr. Med. Chem. 2000, 7, 835-860. [CrossRef] [PubMed]

3. Verlinde, C.L.; Bressi, J.C.; Choe, J.; Suresh, S.; Buckner, F.S.; Van Voorhis, W.C.; Michels, P.A.M.; Gelb, M.H.; Hol, W.G.J. Protein structure-based design of anti-protozoal drugs. J. Braz. Chem. Soc. 2002, 3, 843-844. [CrossRef]

4. Brennand, A.; Rico, E.; Michels, P.A. Autophagy in trypanosomatids. Cells 2012, 1, 346-371. [CrossRef]

5. Biagiotti, M.; Dominguez, S.; Yamout, N.; Zufferey, R. Lipidomics and anti-trypanosomatid chemotherapy. Clin. Transl. Med. 2017, 6, 27. [CrossRef]

6. Verlinde, C.L.; Hannaert, V.; Blonski, C.; Willson, M.; Périé, J.J; Fothergill-Gilmore, L.A.; Opperdoes, F.R.; Gelb, M.H.; Hol, W.G.; Michels, P.A. Glycolysis as a target for the design of new anti-trypanosome drugs. Drug Resist. Updat. 2001, 4, 50-65. [CrossRef] [PubMed]

7. Moyersoen, J.; Choe, J.; Fan, E.; Hol, W.G.; Michels, P.A. Biogenesis of peroxisomes and glycosomes: Trypanosomatid glycosome assembly is a promising new drug target. FEMS Microbiol. Rev. 2004, 28, 603-643. [CrossRef] [PubMed]

8. Varela, M.T.; Fernandes, J.P.S. Natural products: Key prototypes to drug discovery against neglected diseases caused by Trypanosomatids. Curr. Med. Chem. 2020, 27, 2133-2146. [CrossRef]

9. Álvarez-Bardón, M.; Pérez-Pertejo, Y.; Ordóñez, C.; Sepúlveda-Crespo, D.; Carballeira, N.M.; Tekwani, B.L.; Murugesan, S.; Martinez-Valladares, M.; García-Estrada, C.; Reguera, R.M.; et al. Screening marine natural productsfor new drug leads against Trypanosomatids and Malaria. Mar. Drugs 2020, 18, 187. [CrossRef]

10. Proksch, P.; Edrada, R.A.; Ebel, R. Drugs from the seas-Current status and microbiological implications. Appl. Microbiol. Biotechnol. 2002, 59, 125-134. [CrossRef]

11. Shiomi, K.; Ōmura, M.J.A. Antiparasitic agents produced by microorganisms. Proc. Jpn. Acad. Ser. B 2004, 80, 245-258. [CrossRef]

12. Domingues Passero, L.F.; Laurenti, M.D.; Santos-Gomes, G.; Soares Campos, B.L.; Sartoreli, P.; Lago, J.H.G. In vivo antileishmanial activity of plant-based secondary metabolites. In Fighting Multidrug Resistance with Herbal Extracts, Essential Oils and Their Components; Rai, M., Kon, K., Eds.; Academic Press: Cambridge, UK, 2013; Chapter 7; pp. 95-107. [CrossRef]

13. Cruz, A.K.; de Toledo, J.S.; Falade, M.; Terrão, M.C.; Kamchonwongpaisan, S.; Kyle, D.E.; Uthaipibull, C. Current treatment and drug discovery against Leishmania spp. and Plasmodium spp.: A review. Curr. Drug Targets 2009, 10, 178-192. [CrossRef] [PubMed]

14. Requena, J.M.; Iborra, S.; Carrión, J.; Alonso, C.; Soto, M. Recent advances in vaccines for leishmaniasis. Exp.Opin. Biol. Ther. 2004, 4, 1505-1517. [CrossRef] [PubMed]

15. Maurício, I.L.; Stothard, J.R.; Miles, M.A. The strange case of Leishmania chagasi. Parasitol. Today 2000, 16, 188-189. [CrossRef]

16. Grant, K.M.; Dunion, M.H.; Yardley, V.; Skaltsounis, A.L.; Marko, D.; Eisenbrand, G.; Croft, S.L.; Meijer, L.; Mottram, J.C. Inhibitors of Leishmania mexicana CRK3 cyclin-dependent kinase: Chemical library screen and antileishmanial activity. Antimicrob. Agents Chemother. 2004, 48, 3033-3042. [CrossRef]

17. Singh, S.; Sivakumar, R. Challenges and new discoveries in the treatment of leishmaniasis. J. Infect. Chemother. 2004, 10, 307-315. [CrossRef]

18. Liñares, G.E.; Ravaschino, E.L.; Rodriguez, J.B. Progresses in the field of drug design to combat tropical protozoan parasitic diseases. Curr. Med. Chem. 2006, 13, 335-360. [CrossRef] 
19. Caldas, I.S.; Santos, E.G.; Novaes, R.D. An evaluation of benznidazole as a Chagas disease therapeutic. Exp. Opin. Pharmacother. 2019, 20, 1797-1807. [CrossRef]

20. Álvarez, M.G.; Vigliano, C.; Lococo, B.; Bertocchi, G.; Viotti, R. Prevention of congenital Chagas disease by benznidazole treatment in reproductive-age women. An observational study. Acta Trop. 2017, 174, 149-152. [CrossRef]

21. Bermudez, J.; Davies, C.; Simonazzia, A.; Real, J.P.; Palma, S. Current drug therapy and pharmaceutical challenges for Chagas disease. Acta Trop. 2016, 156, 1-16. [CrossRef]

22. Sales, P.A., Jr.; Molina, I.; Fonseca Murta, S.M.; Sánchez-Montalvá, A.; Salvador, F.; Corrêa-Oliveira, R.; Martins Carneiro, C. Experimental and clinical treatment of Chagas disease: A review. Am. J. Trop. Med. Hyg. 2017, 97, 1289-1303. [CrossRef]

23. Annang, F.; Pérez-Moreno, G.; García-Hernández, R.; Cordon-Obras, C.; Martín, J.; Tormo, J.R.; Rodríguez, L.; de Pedro, N.; GómezPérez, V.; Valente, M.; et al. High-throughput screening platform for natural product-based drug discovery against 3 neglected tropical diseases: Human African trypanosomiasis, leishmaniasis, and Chagas disease. J. Biomol. Screen. 2015, 20, 82-91. [CrossRef]

24. Priotto, G.; Kasparian, S.; Mutombo, W.; Ngouama, D.; Ghorashian, S.; Arnold, U.; Ghabri, S.; Baudin, E.; Buard, V.; Kazadi-Kyanza, S.; et al. Nifurtimox-eflornithine combination therapy for second-stage African Trypanosoma brucei gambiense trypanosomiasis: A multicentre, randomised, phase III, non-inferiority trial. Lancet 2009, 374, 56-64. [CrossRef]

25. Deeks, E.D. Fexinidazole: First global approval. Drugs 2019, 79, 215-220. [CrossRef] [PubMed]

26. Mesu, V.K.B.K.; Kalonji, W.M.; Bardonneau, C.; Mordt, O.V.; Blesson, S.; Simon, F.; Delhomme, S.; Bernhard, S.; Kuziena, W.; Lubaki, J.F.; et al. Oral fexinidazole for late-stage African Trypanosoma brucei gambiense trypanosomiasis: A pivotal multicentre, randomised, non-inferiority trial. Lancet 2018, 39, 144-154. [CrossRef]

27. Lindner, A.K.; Lejon, V.; Chappuis, F.; Seixas, J.; Kazumba, L.; Barrett, M.P.; Mwamba, E.; Erphas, O.; Akl, E.A.; Villanueva, G.; et al. New WHO guidelines for treatment of gambiense human African trypanosomiasis including fexinidazole: Substantial changes for clinical practice. Lancet Infect. Dis. 2020, 20, e38-e46. [CrossRef]

28. Leishmaniasis. Available online: https://www.who.int/news-room/fact-sheets/detail/leishmaniasis (accessed on 29 November 2020).

29. Torres-Guerrero, E.; Quintanilla-Cedillo, M.R.; Ruiz-Esmenjaud, J.; Arenas, R. Leishmaniasis: A review. F1000Research 2017, 6, 750. [CrossRef] [PubMed]

30. Davis, A.J.; Kedzierski, L. Recent advances in antileishmanial drug development. Curr. Opin. Investig. Drugs 2005, 6, 163-169.

31. Chagas in the Americas. Available online: https:/ / www.paho.org/hq/index.php?option=com_content\&view=article\&id=13566: chagas-in-americas\&Itemid=40721\&lang=en (accessed on 7 December 2020).

32. Trypanosomiasis, Human African (Sleeping Sickness). Available online: https://www.who.int/news-room/fact-sheets/detail/ trypanosomiasis-human-african-(sleeping-sickness) (accessed on 10 February 2021).

33. Pagmadulam, B.; Tserendulam, D.; Rentsenkhand, T.; Igarashi, M.; Sawa, R.; Nihei, C.I.; Nishikawa, Y. Isolation and characterization of antiprotozoal compound-producing Streptomyces species from Mongolian soils. Parasitol. Int. 2020, 74, 101961. [CrossRef]

34. Pham, J.V.; Yilma, M.A.; Feliz, A.; Majid, M.T.; Maffetone, N.; Walker, J.R.; Kim, E.; Cho, H.J.; Reynolds, J.M.; Song, M.C.; et al. A review of the microbial production of bioactive natural products and biologics. Front. Microbiol. 2019, 10, 1404. [CrossRef]

35. Tempone, A.G.; Martins de Oliveira, C.; Berlinck, R.G. Current approaches to discover marine antileishmanial natural products. Planta Med. 2011, 77, 572-585. [CrossRef] [PubMed]

36. Rocha, L.G.; Almeida, J.R.; Macêdo, R.O.; Barbosa-Filho, J.M. A review of natural products with antileishmanial activity. Phytomedicine 2005, 12, 514-535. [CrossRef]

37. Fatima, N.; Muhammad, S.A.; Mumtaz, A.; Tariq, H.; Shahzadi, I.; Said, M.S.; Dawood, M. Fungal metabolites and leishmaniasis: A review. Br. J. Pharm. Res. 2016, 12, 1-12. [CrossRef]

38. Uddin, G.M.S.; Nejum, M.R.; Islam, M.R.; Islam, M.M. Production of novel antiprotozoal and antihelmintic compounds from marine surface associated bacteria. J. Marine Sci. Res. Dev. 2019, 9, 1000266. [CrossRef]

39. Sayed, K.A.; Khalil, A.A.; Yousaf, M.; Labadie, G.; Kumar, G.M.; Franzblau, S.G.; Mayer, A.M.; Avery, M.A.; Hamann, M.T. Semisynthetic studies on the manzamine alkaloids. J. Nat. Prod. 2008, 71, 300-308. [CrossRef]

40. Peraud, O. Isolation and Characterization of a Sponge-Associated Actinomycete that Produces Manzamines. Ph.D. Thesis, Faculty of the Graduate School of the University of Maryland, College Park, MD, USA, 2006. Available online: http://hdl.handle.net/19 03/4114 (accessed on 20 November 2020).

41. Rao, K.V.; Santarsiero, B.D.; Mesecar, A.D.; Schinazi, R.F.; Tekwani, B.L.; Hamann, M.T. New manzamine alkaloids with activity against infectious and tropical parasitic diseases from an Indonesian sponge. J. Nat. Prod. 2003, 66, 823-828. [CrossRef]

42. Rao, K.V.; Kasanah, N.; Wahyuono, S.; Tekwani, B.L.; Schinazi, R.F.; Hamann, M.T. Three new manzamine alkaloids from a common Indonesian sponge and their activity against infectious and tropical parasitic diseases. J. Nat. Prod. 2004, 67, 1314-1318. [CrossRef] [PubMed]

43. Indraningrat, A.A.; Smidt, H.; Sipkema, D. Bioprospecting sponge-associated microbes for antimicrobial compounds. Mar. Drugs 2016, 14, 87. [CrossRef] [PubMed]

44. Schulze, C.J.; Donia, M.S.; Siqueira-Neto, J.L.; Ray, D.; Raskatov, J.A.; Green, R.E.; McKerrow, J.H.; Fischbach, M.A.; Linington, R.G. Genome-directed lead discovery: Biosynthesis, structure elucidation, and biological evaluation of two families of polyene macrolactams against Trypanosoma brucei. ACS Chem. Biol. 2015, 10, 2373-2381. [CrossRef]

45. Pimentel-Elardo, S.M.; Kozytska, S.; Bugni, T.S.; Ireland, C.M.; Moll, H.; Hentschel, U. Anti-parasitic compounds from Streptomyces sp. strains isolated from Mediterranean sponges. Mar. Drugs 2010, 8, 373-380. [CrossRef] 
46. Pimentel-Elardo, S.M.; Buback, V.; Gulder, T.A.; Bugni, T.S.; Reppart, J.; Bringmann, G.; Ireland, C.M.; Schirmeister, T.; Hentschel, U. New tetromycin derivatives with anti-trypanosomal and protease inhibitory activities. Mar. Drugs 2011, 9, 1682-1697. [CrossRef]

47. Graven, S.N.; Estrada-O, S.; Lardy, H.A. Alkali metal cation release and respiratory inhibition induced by nigericin in rat liver mitochondria. Proc. Natl. Acad. Sci. USA 1966, 56, 654-658. [CrossRef]

48. Ortega, H.E.; Ferreira, L.L.G.; Melo, W.G.P.; Oliveira, A.L.L.; Ramos Alvarenga, R.F.; Lopes, N.P.; Bugni, T.S.; Andricopulo, A.D.; Pupo, M.T. Antifungal compounds from Streptomyces associated with attine ants also inhibit Leishmania donovani. PLoS Negl. Trop. Dis. 2019, 13, e0007643. [CrossRef]

49. Riddell, F.G.; Arumugam, S.; Brophy, P.J.; Cox, B.G.; Payne, M.C.H.; Southon, T.E. The nigericin-mediated transport of sodium and potassium ions through phospholipid bilayers studied by sodium-23 and potassium-39 NMR spectroscopy. J. Am. Chem. Soc. 1988, 110, 734-738. [CrossRef]

50. Miller, P.G.; Klein, R.A. Effects of oligomycin on glucose utilization and calcium transport in African trypanosomes. J. Gen Microbiol. 1980, 116, 391-396. [CrossRef]

51. Nakata, M.; Ishiyama, T.; Akamatsu, S.; Hirose, Y.; Maruoka, H.; Suzuki, R.; Tatsuta, K. Synthetic studies on oligomycins. Synthesis of the oligomycin B spiroketal and polypropionate portions. Bull. Chem. Soc. Jpn. 1995, 66, 967-989. [CrossRef]

52. Lee, H.J.; Moon, J.; Chung, I.; Chung, J.H.; Park, C.; Lee, J.O.; Han, J.A.; Kang, M.J.; Yoo, E.H.; Kwak, S.Y.; et al. ATP synthase inhibitory factor 1 (IF1), a novel myokine, regulates glucose metabolism by AMPK and Akt dual pathways. FASEB J. 2019, 33, 14825-14840. [CrossRef] [PubMed]

53. Martinez-Peinado, N.; Martori, C.; Cortes-Serra, N.; Sherman, J.; Rodriguez, A.; Gascon, J.; Alberola, J.; Pinazo, M.J.; Rodriguez-Cortes, A.; Alonso-Padilla, J. Anti-Trypanosoma cruzi activity of metabolism modifier compounds. Int. J. Mol. Sci. 2021, 22, 688. [CrossRef] [PubMed]

54. Reed, P.W.; Lardy, H.A. A23187: A divalent cation ionophore. J. Biol. Chem. 1972, 247, 6970-6977. [CrossRef]

55. Pressman, B.C. Biological applications of ionophores. Annu. Rev. Biochem. 1976, 45, 501-530. [CrossRef]

56. Buchmüller-Rouiller, Y.; Mauël, J. Macrophage activation for intracellular killing as induced by calcium ionophore. Correlation with biologic and biochemical events. J. Immunol. 1991, 146, 217-223. [PubMed]

57. Lanza, H.; Afonso-Cardoso, S.R.; Silva, A.G.; Napolitano, D.R.; Espíndola, F.S.; Pena, J.D.; Souza, M.A. Comparative effect of ion calcium and magnesium in the activation and infection of the murine macrophage by Leishmania major. Biol. Res. 2004, 37, 385-393. [CrossRef] [PubMed]

58. Grekov, I.; Pombinho, A.R.; Kobets, T.; Bartůněk, P.; Lipoldová, M. Calcium ionophore, calcimycin, kills Leishmania promastigotes by activating parasite nitric oxide synthase. Biomed. Res. Int. 2017, 2017, 1309485. [CrossRef]

59. Dashti, Y.; Grkovic, T.; Abdelmohsen, U.R.; Hentschel, U.; Quinn, R.J. Production of induced secondary metabolites by a co-culture of sponge-associated actinomycetes, Actinokineospora sp. EG49 and Nocardiopsis sp. RV163. Mar. Drugs 2014, 12, 3046-3059. [CrossRef]

60. Abdelmohsen, U.R.; Cheng, C.; Viegelmann, C.; Zhang, T.; Grkovic, T.; Ahmed, S.; Quinn, R.J.; Hentschel, U.; Edrada-Ebel, R. Dereplication strategies for targeted isolation of new antitrypanosomalactinosporins A and B from a marine sponge associatedActinokineospora sp. EG49. Mar. Drugs 2014, 12, 1220-1244. [CrossRef] [PubMed]

61. Tawfike, A.; Attia, E.Z.; Desoukey, S.Y.; Hajjar, D.; Makki, A.A.; Schupp, P.J.; Edrada-Ebel, R.; Abdelmohsen, U.R. New bioactive metabolites from the elicited marine sponge-derived bacterium Actinokineospora spheciospongiae sp. nov. AMB Express $2019,9,12$. [CrossRef] [PubMed]

62. Linington, R.G.; Edwards, D.J.; Shuman, C.F.; McPhail, K.L.; Matainaho, T.; Gerwick, W.H. Symplocamide A, a potent cytotoxin and chymotrypsin inhibitor from the marine cyanobacterium Symploca sp. J. Nat. Prod. 2008, 71, 22-27. [CrossRef]

63. Linington, R.G.; Gonzalez, J.; Ureña, L.D.; Romero, L.I.; Ortega-Barría, E.; Gerwick, W.H. Venturamides A and B: Antimalarial constituents of the panamanian marine cyanobacterium Oscillatoria sp. J. Nat. Prod. 2007, 70, 397-401. [CrossRef]

64. Simmons, T.L.; Engene, N.; Ureña, L.D.; Romero, L.I.; Ortega-Barría, E.; Gerwick, L.; Gerwick, W.H. Viridamides A and B, lipodepsipeptides with antiprotozoal activity from the marine cyanobacterium Oscillatoria nigro-viridis. J. Nat. Prod. 2008, 71, 1544-1550. [CrossRef]

65. Balunas, M.J.; Grosso, M.F.; Villa, F.A.; Engene, N.; McPhail, K.L.; Tidgewell, K.; Pineda, L.M.; Gerwick, L.; Spadafora, C.; Kyle, D.E.; et al. Coibacins A-D, antileishmanial marine cyanobacterial polyketides with intriguing biosynthetic origins. Org. Lett. 2012, 14, 3878-3881. [CrossRef]

66. Balunas, M.J.; Linington, R.G.; Tidgewell, K.; Fenner, A.M.; Ureña, L.D.; Togna, G.D.; Kyle, D.E.; Gerwick, W.H. Dragonamide E, a modified linear lipopeptide from Lyngbya majuscula with antileishmanial activity. J. Nat. Prod. 2010, 73, 60-66. [CrossRef] [PubMed]

67. Liu, L.; Rein, K.S. New peptides isolated from Lyngbya species: A review. Mar. Drugs 2010, 8, 1817-1837. [CrossRef]

68. Sanchez, L.M.; Lopez, D.; Vesely, B.A.; Della Togna, G.; Gerwick, W.H.; Kyle, D.E.; Linington, R.G. Almiramides A-C: Discovery and development of a new class of leishmaniasis lead compounds. J. Med. Chem. 2010, 53, 4187-4197. [CrossRef]

69. Linington, R.G.; Clark, B.R.; Trimble, E.E.; Almanza, A.; Ureña, L.D.; Kyle, D.E.; Gerwick, W.H. Antimalarial peptides from marine cyanobacteria: Isolation and structural elucidation of gallinamide A. J. Nat. Prod. 2009, 72, 14-17. [CrossRef]

70. França, P.H.B.; da Silva-Júnior, E.F.; Santos, B.V.O.; Alexander-Moreira, M.S.; Quintans-Junior, L.S.; de Aquino, T.M.; Araújo-Júnior, J.X. Antileishmanial marine compounds: A review. Rec. Nat. Prod. 2017, 11, 92-113.

71. Ogawa, H.; Iwasaki, A.; Sumimoto, S.; Kanamori, Y.; Ohno, O.; Iwatsuki, M.; Ishiyama, A.; Hokari, R.; Otoguro, K.; Ōmura, S.; et al. Janadolide, a cyclicpolyketide-peptide hybrid possessing a tert-butyl group from an Okeania sp. marine cyanobacterium. J. Nat. Prod. 2016, 79, 1862-1866. [CrossRef] 
72. Athawale, P.R.; Jachak, G.R.; Shukla, A.; Shanmugam, D.; Reddy, D.S. Efforts To access the potent antitrypanosomal marine natural product janadolide: Synthesis of des-tert-butyl janadolide and its biological evaluation. ACS Omega 2018, 3, 2383-2389. [CrossRef]

73. Chung, J.H.; Tang, A.H.; Geraghty, K.; Corcilius, L.; Kaiser, M.; Payne, R.J. Total synthesis and antitrypanosomal activity of janadolide and simplified analogues. Org. Lett. 2020, 22, 3089-3093. [CrossRef] [PubMed]

74. Martínez-Luis, S.; Gómez, J.F.; Spadafora, C.; Guzmán, H.M.; Gutiérrez, M. Antitrypanosomal alkaloids from the marine bacterium Bacillus pumilus. Molecules 2012, 17, 11146-11155. [CrossRef]

75. Giddens, A.C.; Nielsen, L.; Boshoff, H.I.; Tasdemir, D.; Perozzo, R.; Kaiser, M.; Wang, F.; Sacchettini, J.C.; Copp, B.R. Natural product inhibitors of fatty acid biosynthesis: Synthesis of the marine microbial metabolites pseudopyronines A and B and evaluation of their anti-infective activities. Tetrahedron 2008, 64, 1242-1249. [CrossRef]

76. Mutomba, M.C.; Wang, C.C. Effects of aphidicolin and hydroxyurea on the cell cycle and differentiation of Trypanosoma brucei bloodstream forms. Mol. Biochem. Parasitol. 1996, 80, 89-102. [CrossRef]

77. Kayser, O.; Kiderlen, A.F.; Bertels, S.; Siems, K. Antileishmanial activities of aphidicolin and its semisynthetic derivatives. Antimicrob. Agents Chemother. 2001, 45, 288-292. [CrossRef]

78. Ma, G.; Khan, S.I.; Jacob, M.R.; Tekwani, B.L.; Li, Z.; Pasco, D.S.; Walker, L.A.; Khan, I.A. Antimicrobial and antileishmanial activities of hypocrellins A and B. Antimicrob. Agents Chemother. 2004, 48, 4450-4452. [CrossRef]

79. Molinar, E.; Rios, N.; Spadafora, C.; Arnold, A.E.; Coley, P.D.; Kursar, T.A.; Gerwick, W.H.; Cubilla-Rios, L. Coibanoles, a new class of meroterpenoids produced by Pycnoporus sanguineus. Tetrahedron Lett. 2012, 53, 919-922. [CrossRef]

80. do RosárioMarinho, A.M.; Rodrigues-Filho, E.; Moitinho, M.L.R.; Santos, L.S. Biologically active polyketides produced by Penicillium janthinellum isolated as an endophytic fungus from fruits of Melia azedarach. J. Braz. Chem. Soc. 2005, 16, 280-283.

81. Schmidt, A.; Krauth-Siegel, R.L. Enzymes of the trypanothione metabolism as targets for antitrypanosomal drug development. Curr. Top. Med. Chem. 2002, 2, 1239-1259. [CrossRef]

82. Cota, B.B.; Rosa, L.H.; Caligiorne, R.B.; Rabello, A.L.; Almeida Alves, T.M.; Rosa, C.A.; Zani, C.L. Altenusin, a biphenyl isolated from the endophytic fungus Alternaria sp., inhibits trypanothione reductase from Trypanosoma cruzi. FEMS Microbiol. Lett. 2008, 285, 177-182. [CrossRef] [PubMed]

83. Idris, A.; Tantry, M.A.; Ganai, B.A.; Kamili, A.N.; Williamson, J.S. Reduced perylenequinone derivatives from an endophytic Alternaria sp. isolated from Pinus ponderosa. Phytochem. Lett. 2015, 11, 264-269. [CrossRef]

84. Campos, F.F.; Rosa, L.H.; Cota, B.B.; Caligiorne, R.B.; Rabello, A.L.; Alves, T.M.; Rosa, C.A.; Zani, C.L. Leishmanicidal metabolites from Cochliobolus sp., an endophytic fungus isolated from Piptadenia adiantoides (Fabaceae). PLoS Negl. Trop. Dis. 2008, 2, e348. [CrossRef] [PubMed]

85. Martínez-Luis, S.; Della-Togna, G.; Coley, P.D.; Kursar, T.A.; Gerwick, W.H.; Cubilla-Rios, L. Antileishmanial constituents of the Panamanian endophytic fungus Edenia sp. J. Nat. Prod. 2008, 71, 2011-2014. [CrossRef] [PubMed]

86. Ortega, H.E.; Teixeira, E.M.; Rabello, A.; Higginbotham, S.; Cubilla-Ríos, L. Anti-L. donovani activity in macrophage/amastigote model of palmarumycin $\mathrm{CP}_{18}$ and its large scale production. Nat. Prod. Commun. 2014, 9, 95-98. [CrossRef] [PubMed]

87. Osterhage, C.; Kaminsky, R.; König, G.M.; Wright, A.D. Ascosalipyrrolidinone A, an antimicrobial alkaloid, from the obligate marine fungus Ascochyta salicorniae. J. Org. Chem. 2000, 65, 6412-6417. [CrossRef] [PubMed]

88. Brissow, E.R.; da Silva, I.P.; de Siqueira, K.A.; Senabio, J.A.; Pimenta, L.P.; Januário, A.H.; Magalhães, L.G.; Furtado, R.A.; Tavares, D.C.; Sales Junior, P.A.; et al. 18-des-hydroxy cytochalasin: An antiparasitic compound of Diaporthe phaseolorum-92C, an endophytic fungus isolated from Combretum lanceolatum Pohl ex Eichler. Parasitol. Res. 2017, 116, 1823-1830. [CrossRef] [PubMed]

89. Campos, F.F.; Sales Junior, P.A.; Romanha, A.J.; Araújo, M.S.; Siqueira, E.P.; Resende, J.M.; Alves, T.M.; Martins-Filho, O.A.; Santos, V.L.; Rosa, C.A.; et al. Bioactive endophytic fungi isolated from Caesalpinia echinata Lam. (Brazilwood) and identification of beauvericin as a trypanocidal metabolite from Fusarium sp. Mem. Inst. Oswaldo Cruz 2015, 110, 65-74. [CrossRef] [PubMed]

90. Cota, B.B.; Tunes, L.G.; Maia, D.N.B.; Ramos, J.P.; Oliveira, D.M.; Kohlhoff, M.; Alves, T.M.A.; Souza-Fagundes, E.M.; Campos, F.F.; Zani, C.L. Leishmanicidal compounds of Nectria pseudotrichia, an endophytic fungus isolated from the plant Caesalpinia echinata (Brazilwood). Mem. Inst. Oswaldo Cruz. 2018, 113, 102-110. [CrossRef] [PubMed]

91. do Nascimento, J.S.; Silva, F.M.; Magallanes-Noguera, C.A.; Kurina-Sanz, M.; Dos Santos, E.G.; Caldas, I.S.; Luiz, J.H.H.; Silva, E.O. Natural trypanocidalproducto produced by endophytic fungi through co-culturing. Folia Microbiol. 2020, 65, 323-328. [CrossRef] [PubMed]

92. Araki, Y.; Awakawa, T.; Matsuzaki Cho, R.; Matsuda, Y.; Hoshino, S.; Shinohara, Y.; Yamamoto, M.; Kido, Y.; Inaoka, D.K.; Nagamune, K.; et al. Complete biosynthetic pathways of ascofuranone and ascochlorin in Acremonium egyptiacum. Proc. Natl. Acad. Sci. USA 2019, 116, 8269-8274. [CrossRef]

93. Minagawa, N.; Yabu, Y.; Kita, K.; Nagai, K.; Ohta, N.; Meguro, K.; Sakajo, S.; Yoshimoto, A. An antibiotic, ascofuranone, specifically inhibits respiration and in vitro growth of long slender blood stream forms of Trypanosoma brucei brucei. Mol. Biochem. Parasitol. 1997, 84, 271-280. [CrossRef]

94. Saimoto, H.; Kido, Y.; Haga, Y.; Sakamoto, K.; Kita, K. Pharmacophore identification of ascofuranone, potent inhibitor of cyanide-insensitive alternative oxidase of Trypanosoma brucei. J. Biochem. 2013, 153, 267-273. [CrossRef] [PubMed]

95. Yabu, Y.; Yoshida, A.; Suzuki, T.; Nihei, C.; Kawai, K.; Minagawa, N.; Hosokawa, T.; Nagai, K.; Kita, K.; Ohta, N. The efficacy of ascofuranone in a consecutive treatment on Trypanosoma brucei brucei in mice. Parasitol. Int. 2003, 52, 155-164. [CrossRef]

96. Nihei, C.; Fukai, Y.; Kita, K. Trypanosome alternative oxidase as a target of chemotherapy. Biochim. Biophys. Acta 2002, 1587, 234-239. [CrossRef] 
97. Haga, Y.; Tonoi, T.; Anbiru, Y.; Takahashi, Y.; Tamura, S.; Yamamoto, M.; Ifuku, S.; Morimoto, M.; Saimoto, H. A short and efficient total synthesis of $( \pm)$-ascofuranone. Chem. Lett. 2011, 39, 622-623. [CrossRef]

98. Bessho, T.; Morii, S.; Kusumoto, T.; Shinohara, T.; Noda, M.; Uchiyama, S.; Shuto, S.; Nishimura, S.; Djikeng, A.; Duszenko, M.; et al. Characterization of the novel Trypanosoma brucei inosine 5'-monophosphate dehydrogenase. Parasitology 2013, 140, 735-745. [CrossRef] [PubMed]

99. Suganuma, K.; Sarwono, A.E.; Mitsuhashi, S.; Jakalski, M.; Okada, T.; Nthatisi, M.; Yamagishi, J.; Ubukata, M.; Inoue, N. Mycophenolic acid and its derivatives as potential chemotherapeutic agents targeting inosine monophosphate dehydrogenase in Trypanosoma congolense. Antimicrob. Agents Chemother. 2016, 60, 4391-4393. [CrossRef]

100. Zulfiqar, B.; Jones, A.J.; Sykes, M.L.; Shelper, T.B.; Davis, R.A.; Avery, V.M. Screening a natural product-based library against kinetoplastid parasites. Molecules 2017, 22, 1715. [CrossRef]

101. Endo, A.; Kuroda, M.; Tsujita, Y. ML-236A, ML-236B, and ML-236C, new inhibitors of cholesterogenesis produced by Penicillium citrinium. J. Antibiot. 1976, 29, 1346-1348. [CrossRef]

102. Dinesh, N.; Soumya, N.; Singh, S. Antileishmanial effect of mevastatin is due to interference with sterol metabolism. Parasitol. Res. 2015, 114, 3873-3883. [CrossRef]

103. Pontius, A.; Krick, A.; Kehraus, S.; Brun, R.; König, G.M. Antiprotozoal activities of heterocyclic-substituted xanthones from the marine-derived fungus Chaetomium sp. J. Nat. Prod. 2008, 71, 1579-1584. [CrossRef]

104. Rodrigues, A.G. Secondary metabolism and antimicrobial metabolites of Aspergillus. In New and Future Developments in Microbial Technology and Bioengineering: Aspergillus System Properties and Applications; Gupta, V.K., Ed.; Elsevier BV: Amsterdam, The Netherlands, 2016; Chapter 6; pp. 81-93. [CrossRef]

105. Saeedi, M.; Eslamifar, M.; Khezri, K. Kojic acid applications in cosmetic and pharmaceutical preparations. Biomed. Pharmacother. 2019, 110, 582-593. [CrossRef]

106. Rodrigues, A.P.; Farias, L.H.; Carvalho, A.S.; Santos, A.S.; do Nascimento, J.L.; Silva, E.O. A novel function for kojic acid, a secondary metabolite from Aspergillus fungi, as antileishmanial agent. PLoS ONE 2014, 9, e91259. [CrossRef]

107. Da Costa, J.P.; Rodrigues, A.P.D.; Farias, L.H.S.; Frade, P.C.R.; Da Silva, B.J.M.; Do Nascimento, J.L.M.; Silva, E.O. Biological effects of kojic acid on human monocytes in vitro. Biomed. Pharmacother. 2018, 101, 100-106. [CrossRef]

108. Malak, L.G.; Ibrahim, M.A.; Bishay, D.W.; Abdel-Baky, A.M.; Moharram, A.M.; Tekwani, B.; Cutler, S.J.; Ross, S.A. Antileishmanial metabolites from Geosmithia langdonii. J. Nat. Prod. 2014, 77, 1987-1991. [CrossRef] [PubMed]

109. Malak, L.G.; Ibrahim, M.A.; Moharram, A.M.; Pandey, P.; Tekwani, B.; Doerksen, R.J.; Ferreira, D.; Ross, S.A. Antileishmanial carbasugars from Geosmithia langdonii. J. Nat. Prod. 2018, 81, 2222-2227. [CrossRef]

110. Atencio, N.; Miller, K.; Cheney, A.; Benally, B.A. The anti-leishmanial effects of compounds derived from the fungus Geosmithia langdonii on visceral leishmaniasis. FASEB J. 2020, 34. [CrossRef]

111. Gao, J.; Radwan, M.M.; León, F.; Wang, X.; Jacob, M.R.; Tekwani, B.L.; Khan, S.I.; Lupien, S.; Hill, R.A.; Dugan, F.M.; et al. Antimicrobial and antiprotozoal activities of secondary metabolites from the fungus Eurotium repens. Med. Chem. Res. 2012, 21, 3080-3086. [CrossRef] [PubMed]

112. Luque-Ortega, J.R.; Cruz, L.J.; Albericio, F.; Rivas, L. The antitumoral depsipeptide IB-01212 kills Leishmania through an apoptosis-like process involving intracellular targets. Mol. Pharm. 2010, 7, 1608-1617. [CrossRef]

113. Hashida, J.; Niitsuma, M.; Iwatsuki, M.; Mori, M.; Ishiyama, A.; Namatame, M.; Nishihara-Tsukashima, A.; Nonaka, K.; Ui, H.; Masuma R.; et al. Pyrenocine I, a new pyrenocine analog produced by Paecilomyces sp. FKI-3573. J. Antibiot. 2010, 63, 559-561. [CrossRef]

114. Braun, G.H.; Ramos, H.P.; Candido, A.C.B.B.; Pedroso, R.C.N.; Siqueira, K.A.; Soares, M.A.; Dias, G.M.; Magalhães, L.G.; Ambrósio, S.R.; Januário, A.H.; et al. Evaluation of antileishmanial activity of harzialactone A isolated from the marine-derived fungus Paecilomyces sp. Nat. Prod. Res. 2019, 29, 1-4. [CrossRef] [PubMed]

115. Vivero Gómez, R.J.; Cadavid Restrepo, G.E.; Moreno Herrera, C.X.; Ospina, V.; Uribe, S.I.; Robledo, S.M. Antagonistic effect of bacteria isolated from the digestive tract of Lutzomyia evansi against promastigotes of Leishmania infantum, antimicrobial activities and susceptibility to antibiotics. Adv. Microbiol. 2016, 6, 760-775. [CrossRef]

116. Vivero, R.J.; Mesa, G.B.; Robledo, S.M.; Herrera, C.X.M.; Cadavid-Restrepo, G. Enzymatic, antimicrobial, and leishmanicidal bioactivity of gram-negative bacteria strains from the midgut of Lutzomyia evansi, an insect vector of leishmaniasis in Colombia. Biotechnol. Rep. 2019, 24, e00379. [CrossRef]

117. Li, T.; Ding, T.; Li, J. Medicinal purposes: Bioactive metabolites from marine-derived organisms. Mini Rev. Med. Chem. 2019, 19, 138-164. [CrossRef]

118. Nweze, J.A.; Mbaoji, F.N.; Li, Y.M.; Yang, L.Y.; Huang, S.S.; Chigor, V.N.; Eze, E.A.; Pan, L.X.; Zhang, T.; Yang, D.F. Potentials of marine natural products against malaria, leishmaniasis, and trypanosomiasis parasites: A review of recent articles. Infect. Dis. Poverty 2021, 10, 9. [CrossRef] [PubMed]

119. de Menezes, G.C.A.; Porto, B.A.; Amorim, S.S.; Zani, C.L.; de Almeida Alves, T.M.; Junior, P.A.S.; Murta, S.M.F.; Simões, J.C.; Cota, B.B.; Rosa, C.A.; et al. Fungi in glacial ice of Antarctica: Diversity, distribution and bioprospecting of bioactive compounds. Extremophiles 2020, 24, 367-376. [CrossRef] [PubMed]

120. Ogaki, M.B.; Coelho, L.C.; Vieira, R.; Neto, A.A.; Zani, C.L.; Alves, T.M.A.; Junior, P.A.S.; Murta, S.M.F.; Barbosa, E.C.; Oliveira, J.G.; et al. Cultivable fungi present in deep-sea sediments of Antarctica: Taxonomy, diversity, and bioprospecting of bioactive compounds. Extremophiles 2020, 24, 227-238. [CrossRef] [PubMed] 
121. Toghueo, R.M.K. Anti-leishmanial and anti-inflammatory agents from endophytes: A review. Nat. Prod.Bioprospect. 2019, 9, 311-328. [CrossRef] [PubMed]

122. Rahman, L.; Shinwari, Z.K.; Iqrar, I.; Rahman, L.; Tanveer, F. An assessment on the role of endophytic microbes in the therapeutic potential of Fagonia indica. Ann. Clin. Microbiol. Antimicrob. 2017, 16, 53. [CrossRef] [PubMed]

123. Ungogo, M.A.; Ebiloma, G.U.; Ichoron, N.; Igoli, J.O.; de Koning, H.P.; Balogun, E.O. A review of the antimalarial, antitrypanosomal, and antileishmanial activities of natural compounds isolated from Nigerian flora. Front. Chem. 2020, 8, 617448. [CrossRef] [PubMed]

124. Field, M.C.; Horn, D.; Fairlamb, A.H.; Ferguson, M.A.; Gray, D.W.; Read, K.D.; De Rycker, M.; Torrie, L.S.; Wyatt, P.G.; Wyllie, S.; et al. Anti-trypanosomatid drug discovery: An ongoing challenge and a continuing need. Nat. Rev. Microbiol. 2017, 15, 217-231. [CrossRef]

125. Bhattacharya, A.; Corbeil, A.; do Monte-Neto, R.L.; Fernandez-Prada, C. Of drugs and trypanosomatids: New tools and knowledge to reduce bottlenecks in drug discovery. Genes 2020, 11, 722. [CrossRef] [PubMed]

126. Baell, J.B.; Holloway, G.A. New substructure filters for removal of pan assay interference compounds (PAINS) from screening libraries and for their exclusion in bioassays. J. Med. Chem. 2010, 53, 2719-2740. [CrossRef]

127. Baell, J.B. Feeling nature's PAINS: Natural products, natural product drugs, and pan assay interference compounds (PAINS). J. Nat. Prod. 2016, 79, 616-628. [CrossRef]

128. Baell, J.B.; Nissink, J.W.M. Seven year itch: Pan-assay interference compounds (PAINS) in 2017-Utility and limitations. ACS Chem. Biol. 2018, 13, 36-44. [CrossRef] [PubMed]

129. Katsuno, K.; Burrows, J.N.; Duncan, K.; Hooft van Huijsduijnen, R.; Kaneko, T.; Kita, K.; Mowbray, C.E.; Schmatz, D.; Warner, P.; Slingsby, B.T. Hit and lead criteria in drug discovery for infectious diseases of the developing world. Nat. Rev. Drug. Discov. 2015, 14, 751-758. [CrossRef] [PubMed] 